\author{
University of Texas Rio Grande Valley \\ ScholarWorks @ UTRGV
}

\title{
The dark side of transparency in developing countries: The link between financial reporting practices and corruption
}

Tingting Liu

Yu Liu

Barkat Ullah

Zuobao Wei

Lixin Colin Xu

Follow this and additional works at: https://scholarworks.utrgv.edu/ef_fac

Part of the Finance Commons

\section{Recommended Citation}

Liu, T., Liu, Y., Ullah, B., Wei, Z., Xu, L.C., 2021. The dark side of transparency in developing countries: The link between financial reporting practices and corruption. Journal of Corporate Finance 66, 101829.

https://doi.org/10.1016/j.jcorpfin.2020.101829

This Article is brought to you for free and open access by the Robert C. Vackar College of Business \& Entrepreneurship at ScholarWorks @ UTRGV. It has been accepted for inclusion in Economics and Finance Faculty Publications and Presentations by an authorized administrator of ScholarWorks @ UTRGV. For more information, please contact justin.white@utrgv.edu,william.flores01@utrgv.edu. 


\title{
The Dark Side of Transparency in Developing Countries: The Link between Financial Reporting Practices and Corruption
}

\author{
Tingting Liu \\ Iowa State University, Ames, Iowa \\ Email: ttliu@iastate.edu \\ Yu Liu \\ University of Texas Rio Grande Valley, Edinburg, Texas \\ Email: yu.liu@utrgv.edu \\ Barkat Ullah \\ Morgan State University, Baltimore, Maryland \\ Email: barkat.ullah@morgan.edu \\ Zuobao Wei * \\ University of Texas at El Paso, El Paso, Texas \\ Email: zwei@utep.edu \\ Lixin Colin Xu \\ The World Bank, Washington, D.C. \\ Email: 1xu1@worldbank.org
}

November 14, 2020

\footnotetext{
* Corresponding author. We are grateful for very helpful comments from two anonymous reviewers, Douglas Cumming (the editor), Robert Bloomfield, Yangyang Chen, Shimin Chen, Henrik Cronqvist, Erik Devos, Juliet D’Souza, Sadok El Ghoul, Xin Hong, Bihong (Jenny) Huang, Ying Huang, Yuhchang Hwang, Haekwon Lee, Liang Neng, Lydia Price, Xiaolin (Audrey) Qian, Vivek Singh, Muhammad Moshfique Uddin, Oscar Varela, Fang Yu, Xinge Zhao, Hua Zhang, Tian Zhu, and discussants at the FMA Annual Meeting, the China International Conference in Finance, the FMA European conference, the Southern Finance Association Annual Meeting, the China-Europe Business School (Shanghai, China) and Zhejiang University (Hangzhou, China). We also thank Julian Vogel, Angela Zhou, and Yicheng Zhu for their excellent research assistant work. The views reflected in this paper are the authors' own and do not implicate those of the World Bank, its executive directors, or the countries they represent.
} 


\title{
The Dark Side of Transparency in Developing Countries: The Link between Financial Reporting Practices and Corruption
}

\begin{abstract}
This paper examines the impact of financial reporting practices on corruption obstacles for about 150,000 firms across 143 mostly developing countries from 2006-2019. We document a strong positive relationship between the production of audited financial statements $(A F S)$ and corruption obstacles (CO) faced by the firm. We argue that in a corrupt business environment, rent-seeking bureaucrats use the credible financial information to optimize their bribe demands. Our baseline results remain robust after addressing endogeneity concerns. We further show that country-level institutional quality has a moderating effect on the $A F S-\mathrm{CO}$ relation. The evidence from surveying entrepreneurs also provides qualitative support for our empirical findings. Our study sheds light on a previously under-explored adverse consequence of transparency - exposure to corrupt bureaucrats where institutions are weak.
\end{abstract}

JEL Classification: M42, G32, D73

Key Words: Audited financial statements; Transparency; Private firms; Corruption obstacles 


\section{"[E]mbezzle according to one's rank."}

-- Russian adage from Cadot (1987)

\section{Introduction}

A scene from a New York mob movie could go like this. Big Tuna, the collector, goes to Frankie, the shopkeeper, to collect "protection money." Frankie demurs, "Boss, times are tough. Please cut me some slack." Big Tuna doesn't skip a beat, "Frankie, don't be stupid! We know exactly how much you pulled in this month." Haplessly looking at Big Tuna, Frankie reluctantly opens a drawer and hands over a pre-bundled roll of cash. Big Tuna taps Frankie's shoulder twice, and says "Good boy," before walking toward a bakery across the street.

In developing countries with weak institutions and resulting rampant public corruption, rent-seeking bureaucrats behave like Big Tunas. ${ }^{1}$ They gather and utilize information to maximize the nature and amount of their harassment, subject to the constraints that the firm might exit or they might be caught (Bliss and Tella, 1997; Svensson, 2003, 2005; Fisman and Svensson, 2007). In a dynamic corruption model under different information sets (perfect, imperfect, and incomplete information), Cadot (1987) shows that corrupt behaviors are directly linked to the information sets of the players. He further shows that corrupt officials and bribers derive their Nash strategies based on the information sets they possess. Specifically, he shows that high-ranking officials are able to collect more bribes due to their more complete information sets, thus they "embezzle according to one's rank" (Cadot, 1987, p. 240). Admati and Pfleiderer (2000) analyze a disclosure model by firms and show that disclosure is costly and that the Nash equilibrium of a voluntary disclosure game is often socially inefficient. Durnev and Guriev (2011) also develop a model that shows increased corporate transparency exposes firms to rent-seeking bureaucrats. Johnson et al. (1998) also argue that the high costs associated with corruption and bureaucracy can drive private businesses underground.

Despite extensive theoretical studies showing that costs are associated with increased information production, empirical evidence at the firm level is limited, and empirical evidence from developing countries is even scarcer. In this study, we examine the financial reporting practices of private firms in developing countries. Specifically, we investigate the relation between a firm's financial reporting practices and the associated costs (the dark side) as proxied by firm-

\footnotetext{
${ }^{1}$ For papers and surveys on the literature of corruption, see Bardhan (1997), Cai et al. (2011), Clarke and Xu (2004), Li et al. (2000), Mauro (1995), Murphy et al. (1993), and Svensson (2003, 2005).
} 
level corruption obstacles, that is, whether Frankie's financial reporting practices have an impact on Big Tuna's demand for "protection money."

We focus on private sector firms in developing countries for two reasons. First, private sector plays an increasingly important role in developing economies around the world and there is compelling evidence that the private sector is critical to economic growth in these countries. Until 2014 , the private sector provided about $90 \%$ of employment in the developing world. Furthermore, the private sector funded $60 \%$ of investment and contributed more than $80 \%$ of government revenue in low- and middle-income countries. ${ }^{2}$ Compared with the large literature on developed countries' accounting systems and managers' reporting incentives, financial reporting of private firms in developing countries is highly underexplored in the literature (Chen et al., 2011). Second and more importantly, a growing literature suggests that corruption is often high in developing countries as bureaucrats in developing countries are less constrained than their counterparts in the developed world (Svensson, 2005; Olken and Pande, 2012). In addition, the costs of corruption in these countries can be severe, as corruption may decrease business activities and lead to inefficient outcomes (Shleifer and Vishny, 1994; Mauro, 1995; Murphy et al., 1993; Wei, 2000; Svensson, 2003, 2005; Olken and Pande, 2012). This setting is particularly relevant in our study, as we argue that when corrupt officials are unconstrained, they will find ways to access and abuse firms' audited financial information for personal gains.

Using World Bank Enterprise Survey (WBES) data from 2006-2019 for about 150,000 firms in 143 mostly developing countries, ${ }^{3}$ we examine the impact of the production of audited financial statements (hence forth $A F S$ ) on corruption obstacles (CO) faced by the firm. We document that $A F S$ firms are associated with a significantly higher level of $C O$ than non-AFS firms. Our results are robust to the inclusion of firm-level controls, macro-level controls, and industry, year, and country fixed effects.

We acknowledge the endogenous nature of our key variable, AFS. To alleviate the endogeneity concerns, we employ several strategies, including an instrumental variable (IV) analysis, a panel data analysis with firm fixed effects to control for any unobservable firm

\footnotetext{
2 The source of these statistics is the Australian Department of Foreign Affairs and Trade. https://www.google.com/url?sa=t\&rct=j\&q=\&esrc=s\&source=web\&cd=\&ved=2ahUKEwiA5bjf54TqAhUIG80KHe qPDusQFjACegQIAhAB\&url=https\%3A\%2F\%2Fwww.aph.gov.au\%2FDocumentStore.ashx\%3Fid\%3D53a5f52f5ee9-414b-879b-6bbcdb7e8678\%26subId\%3D252459\&usg=AOvVaw0CkVkNNIBpgeqhsEa_HFCB

${ }^{3}$ Our sample also includes a few mid-income/developed countries, such as Slovenia, South Korea, and Sweden.
} 
characteristics, a regression discontinuity design (RDD) analysis with mandatory country-level audit thresholds, and a qualitative analysis (i.e. an unstructured survey of business owners). Our baseline results remain robust after we run the aforementioned empirical robustness tests. ${ }^{4} \mathrm{An}$ unstructured survey of business owners also provides qualitative support to our hypothesis that increased disclosure of accounting information bears costs in the form of an increased level of corruption obstacles faced by the firm. ${ }^{5}$

To understand how $A F S$ might affect $\mathrm{CO}$, we investigate four variables that arise from the interactions between firms and bureaucrats: business license obstacles, customs obstacles, the percent of senior management's time spent on government regulations, and tax inspections. Our results show that $A F S$ is positively associated with all the four variables. These results are consistent with the notion that bureaucrats' rent-seeking opportunities are positively linked to access to firms' detailed financial information.

We further investigate how country-level institutional development affects the AFS-CO relationship and document a stronger (weaker) relation between $A F S$ and $\mathrm{CO}$ in countries with a weak (strong) corruption control mechanisms. These results provide further evidence that considerable costs are associated with the production of detailed and credible financial information, especially in countries where institutions are underdeveloped and bureaucrats are less constrained.

Our paper contributes to the literature in several aspects. First, and most importantly, our main finding that $A F S$ is linked to higher corruption obstacles at the firm level demonstrates that transparency bears significant costs by exposing the firm to corrupt officials. The existing empirical literature concerning the consequences of financial disclosure has largely focused on the reduction of information asymmetry between firms and non-governmental outside stakeholders. A general finding is that the decrease in information asymmetry reduces the cost of external financing and thus enhances firm investment efficiency (e.g., Leuz and Verrecchia, 2000; Verrecchia, 2001; Bushman and Smith, 2003; Fan and Wong, 2005; Khurana et al., 2006; Guedhami and Pittman, 2006; Hughes et al., 2007; Lambert et al., 2007; Guedhami et al., 2009; Francis et al., 2011; Chen et al., 2011; Hope et al., 2011; DeFond and Zhang, 2014). Despite the large volume of literature documenting the benefits of financial transparency, empirical evidence

\footnotetext{
${ }^{4} \mathrm{We}$ also employ the propensity score matching (PSM) method to alleviate endogeneity concerns. The PSM results, which are not presented in the main text to save space, support the positive relationship between AFS and CO.

${ }^{5}$ See Section 5.4 and Table 6 for details about our survey and interview responses.
} 
on the associated costs is limited. Our finding regarding the dark side of exposing firms to government expropriation is novel and rarely explored empirically in the literature.

Second, our study helps fill a literature gap that private firms' financial reporting practices in developing countries and their consequences are largely unexplored in the literature, as emphasized in Chen et al. (2011) and Cassar (2011). Several papers study financial reporting practices of private firms in developed countries. Using the U.S. Employing survey data from 4,004 small privately held U.S. firms from 2003-2004, Allee and Yohn (2009) examine the factors associated with the production and use of unaudited financial statements, audited financial statements, and accrual-based financial statements. The authors show that firms with audited financial statements have better access to credit than those without. These results show that the sophistication of financial statements plays an important role in lowering financial constraints among privately held small firms in the U.S. Similarly, Minnis (2011) examines a large sample of privately held U.S. firms and documents that firms with AFS experience significantly lower cost of debt than those with unaudited financial statements. More recently, Minnis and his coauthors show that lenders (banks) use $A F S$ as an effective monitoring and information gathering mechanism (Minnis and Sutherland, 2017; see also, Berger et al., 2017). Unlike these studies that focus on the benefits of increased financial disclosure in private firms in the United States, we focus on the associated costs borne by private firms in developing countries. Given that a large majority of firms in our sample are not mandated to produce $A F S$, the results presented in this paper enhance our understanding of private firms' financial disclosure decisions and the associated costs in developing countries. ${ }^{6}$

Third, our paper adds to the literature that examines the costs associated with information production in developed countries. Focusing on U.S. firms, DeAngelo (1988) examines the costs associated with the use of accounting information in proxy fights in U.S. listed firms. Guo et al. (2004) investigate the competitive costs associated with product-related information disclosed in IPO prospectuses. Berger and Hann (2007) examine the proprietary costs and agency costs associated with segment profit information disclosure in U.S. listed firms. The costs examined in these studies are borne by the interactions between firms and non-government outside stakeholders,

\footnotetext{
${ }^{6}$ In our sample, a small number of private firms are required to produce audited financial statements because some countries have policies that require firms to audit their financial statements if they meet certain disclosure thresholds such as total assets or number of employees. See Section 5.3 and Internet Appendix Table IA3 for more details.
} 
such as capital market participants and competitors. On the other hand, the cost examined in our paper arises from the interactions between firms and government bureaucrats, which are especially consequential in developing countries. ${ }^{7}$

Finally, we document that a country's institutional quality plays an important role in impacting the AFS-CO relation. The quality of both governance and institutions have been shown to significantly affect firm-level corporate policies and outcomes (La Porta et al., 2000; Lemmon and Lins, 2003; Doidge et al., 2007; Barth et al., 2009; Durnev et al., 2009; Durnev and Fauver, 2011; Harrison et al., 2014, among others). However, the empirical literature has not paid enough attention to how institutional quality affects firm-level costs associated with financial reporting practices. Our study helps fill the gap. Indeed, the dependence of the AFS effect on institutional background nicely illustrates the complementarity between information disclosure and the underlying institutional background, which is vastly underexplored in the literature but emphasized by Leuz and Wysocki (2008) in their survey.

Our paper is also related to Durnev et al. (2009) who employ data from 69 countries to examine the effect of transparency on firm growth at the industry level. They find that in countries with secure property rights, corporate transparency improves investment efficiency and increases firm growth by lowering information asymmetry. However, in countries with insecure property rights, greater transparency increases the risk of government expropriation, leading some firms to adopt sub-optimal transparency levels (Johnson et al., 1998). At the firm level, Durnev and Fauver (2011) examine a sample of over 20,000 publicly listed firms from 46 countries and find a negative link between the expropriation risk and the degree of information disclosure. They find that in countries with high expropriation risk, firms are discouraged from practicing good governance and choose to disclose less information to avoid government expropriation. Our study complements Durnev et al. (2009) and Durnev and Fauver (2011) in two crucial respects. First, the aforementioned papers examine listed firms, whereas our sample focuses on private firms. As pointed out earlier, publicly listed firms and private firms face very different market and regulatory pressures that shape their financial reporting decisions. Second, we examine the relationship

\footnotetext{
${ }^{7}$ Two studies find that transparency leads to lower level of corruption. Peisakhin (2012) examines the impact of India's version of Freedom of Information Act (RITA) on bribery and finds that the enactment of RITA in 2005 leads to lower incidence of bribery. Akins et al. (2017) find that banks' improved financial reporting reduces lending corruption. Specifically, the authors show that more-timely loan loss provisioning leads to earlier detection of lending corruption.
} 
between $A F S$ and $C O$ from very different angles. Durnev et al. (2009) and Durnev et al. (2011) study the effect of expropriation risk on firm disclosure policies, whereas our paper examines the opposite direction of the causal relationship, that is, the impact of firm disclosure policies (AFS) on $C O$ faced by firms. ${ }^{8}$

The rest of this paper is organized as follows. Section 2 reviews pertinent prior literature and develops our hypothesis. Section 3 describes data, variable definitions, and summary statistics. Section 4 examines the effect of $A F S$ on CO, while Section 5 addresses potential endogeneity concerns. Section 6 discusses several specific channels through which corrupt officials could potentially use the disclosed financial information to optimize bribes. Section 7 examines the impact of institution quality on the $A F S$-CO relation, while Section 8 concludes.

\section{Hypothesis Development}

Our paper is theoretically rooted in the information asymmetry thesis pioneered by George Akerlof (Akerlof, 1970). Information asymmetry exists as insiders know more about the characteristics and quality of their products than outside stakeholders. In an opaque information environment, good quality firms are unable to distinguish themselves from "lemons." To alleviate this information asymmetry, outside stakeholders incur costs to gather and verify information about firm qualities. These costs will be passed on to the insiders eventually. Therefore, insiders in good quality firms have incentives to reduce information asymmetry. Otherwise, they will all be treated like "lemons" in the marketplace.

The disclosure of financial reports reduces information asymmetry between firms and outside stakeholders. The main objective of an external audit is to provide a firm's financial position to outside stakeholders such as equity investors and creditors. ${ }^{9}$ These outside stakeholders

\footnotetext{
8 The fact that Durvev and Fauver (2011) find a negative relationship between increased expropriation risk and disclosure transparency helps strengthen our findings. If higher expropriation risk leads to lower information transparency as documented in Durvev and Fauver (2011), then firms that face higher corruption obstacles are likely to have less incentive to produce $A F S$. Therefore, this reverse causality would work against our finding a positive relation between $A F S$ and CO. Despite this potential negative bias, we still find a positive and significant coefficient of $A F S$, supporting the robustness of our findings.

${ }^{9}$ The International Accounting Standards Board (IASB), which sets financial reporting standards that have been adopted by many countries, states the main objective of financial reporting as follows: "The objective of general purpose financial reporting is to provide financial information about the reporting entity that is useful to existing and potential investors, lenders, and other creditors in making decisions about providing resources to the entity. Those decisions involve buying, selling or holding equity and debt instruments, and providing or settling loans and other forms of credit."
} 
are economic agents who use the information to maximize their respective utilities. Equity investors use the information to gauge the risk-return tradeoff of the investment, while creditors use the information to examine the creditworthiness of the firm. As a result, the cost of market exchanges decreases, benefiting both outside stakeholders and firms (Williamson, 1985). Diamond (1985) develops a theory of voluntary information disclosure using publicly traded firms and shows that at equilibrium, disclosure improves the welfare of all traders more than non-disclosure.

When firms choose their disclosure policies, they also consider potential costs associated with financial disclosure (Watts and Zimmerman, 1978, 1986). For example, the risk of government intervention and expropriation may affect the level of firm disclosure as firms that face a higher risk of state expropriation may act more opaquely. Stulz (2005) argues that country attributes and institutions affect firm-level financial decisions. The agency problem arising from the fact that both sovereign states and firm insiders attempt to squeeze out benefits from outsiders may prevent firms from benefiting from financial globalization. These "dual agency problems" help explain the variations in firm-level corporate decisions (including disclosure policies) across the globe.

There are two main reasons that firms have their financial statements audited by external auditors. The first is a regulatory requirement triggered when the firm meets certain thresholds, such as number of employees or sales (see Section 6.3). The second reason is because they want to apply for external debt or attract new equity capital. The audited financial statements will be submitted to either government agencies or to banks that in developing countries, are largely statecontrolled. Therefore, voluntary or otherwise, the detailed and credible financial information contained in the audited statements will be more readily available for corrupt bureaucrats to exploit compared to firms that do not produce audited financial statements.

In her seminal work on corruption, Rose-Ackerman (1975) models the destructive effect of corruption on economic growth. Johnson et al. (1998) advance corruption research empirically by showing that corruption leads to a larger unofficial economy. Their evidence also suggests that lax discretion in enforcing laws and undisciplined bureaucracies lead to weak supervision of officials. These conditions provide opportunities for corruption and that corruption, in turn, helps drive firms underground. Despite the fact that Johnson et al. (1998) examine the opposite direction of the causal relationship than we do and they examine the phenomenon at the macro level, their 
finding that corruption has a direct impact on a firm's transparency decisions is particularly relevant to our study.

We expect that more transparency provides outsiders with information about firms' revenue, profits, or cash holdings. Like the story we present at the beginning of our study, Big Tuna knew how much Frankie had made and embezzled accordingly. When firms increase their financial transparency, government officials may have a better idea about who should be extorted and how much can be extorted. Furthermore, as discussed in the introduction, we expect that the quality of governance and institutions will have an impact on firm-level disclosure policies and corruption obstacles. Based on the above discussions, we present our hypotheses as follows:

H1: All else equal, higher the production of information, via audited financial statements (AFS), higher is the level of corruption obstacles faced by firms.

H2: The strength of the link between firm corruption obstacles and AFS is stronger (weaker) in countries with relatively lower (higher) institution quality.

\section{Data and Summary Statistics}

\subsection{The Data}

We construct firm-level variables from the WBES, which includes comprehensive firmlevel data collected for about 150,000 firms in 143 countries from 2006-2019. ${ }^{10}$ The WBES relies on standardized survey instruments in collecting firm-level data. Sample firms tend to be random samples from selected cities in each country, and thus the data cover (largely) private firms of all sizes. The survey respondents are mainly business owners and/or top managers at firms. The surveys focus on assessing the critical obstacles in the business environment that hinder firm growth, including access to finance and obstacles related to corruption, political instability, infrastructure, crime, competition, the labor market, and the legal system. The surveys also contain information on firm ownership, sales, employees, top manager's work experience, whether a firm is an exporter, and firm age.

\footnotetext{
${ }^{10}$ Appendix 1 lists the total number of firm observations and the number and percentage of $A F S$ firms and non-AFS firms by country. For a literature survey of firm-level studies using the WBES data, see Xu (2011).
} 
Starting with all observations in the WBES, we delete firms that do not answer the audit question: "In the last fiscal year, did this establishment have its annual financial statement checked and certified by an external auditor?" This question was answered by 148,199 firms in 143 countries from 2006-2019; 51\% of these firms had their annual financial statements checked and certified by external auditors. ${ }^{11}$ Throughout our analysis, we control for country-level governance, institutional and macroeconomic variables. See Section 3.2 and Appendix 2 for a detailed explanation of the country-level variables.

\subsection{Variables and Summary Statistics}

We first describe our dependent variables. ${ }^{12}$ Our primary analyses focus on corruption obstacles (CorruptionObstacle). Firm-level corruption obstacles take on a value based on the selfreported answers to the following WBES question: "How problematic is corruption for the current operations of the business?" The obstacles are measured on a scale from 0 to 4: no obstacles $(0)$, minor obstacles (1), moderate obstacles (2), major obstacles (3), and very severe obstacles (4). As a robustness check, we replace CorruptionObstacle with a dummy variable, CorruptionDummy, in our baseline regressions. CorruptionDummy takes a value of 1 if the corruption obstacle scores equal 2 (moderate), 3 (major), or 4 (very severe), and 0 if the scores are 0 (no obstacle) or 1 (minor obstacle).

We further use two additional firm-level obstacles as dependent variables: business licensing- and permits-related obstacles (LicenseObstacle) and customs-related obstacles (CustomsObstacle). These two obstacles are measured similarly as CorruptionObstacle on a scale from 0 to 4 , with 0 indicating no obstacles and 4 indicating very severe obstacles. We consider these two obstacles to be alternative measures of corruption obstacles as they measure the difficulties arising from firms' direct interactions with government bureaucrats.

We also use two relatively more objective measures related to direct interactions with bureaucrats as our alternative dependent variables, specifically, "What \% of senior management

\footnotetext{
${ }^{11}$ We acknowledge that there are quality variations of financial audits across our sample countries. This concern is mitigated by the fact that most of the countries in our sample have adopted the International Financial Reporting Standards (IFRS). According to the IFRS, www.ifrs.org, IFRS standards are now required in more than 140 jurisdictions and permitted in many others. More importantly, in 166 jurisdictions, IFRS for non-listed SMEs standards are required or permitted. In our Appendix 1, the "*" next to the country name indicates IFRS adoption. In our sample, $85 \%$ of the countries have adopted IFRS. In another mitigation strategy, we control for country-fixed effect in our regressions.

12 Appendix 2 details the variables and their sources.
} 
time was spent in dealing with government regulations?" (TimeonGovernment), and "Over the last 12 months, was this establishment inspected by tax officials?" (TaxInspection). We argue that TimeonGovernment and CorruptionObstacle are two closely related variables. The higher the odds that the firm incurs corruption-related costs, the more time the senior management spends in dealing with government regulations. We also expect that TaxInspection and CorruptionObstacle are positively linked, as Alm et al. (2016) indicate that tax inspection is positively related to bribes.

Panel A in Table 1 reports summary statistics for our full sample. On average, our sample firms experience close to moderate corruption obstacles (mean $=1.71)$, minor license obstacles $($ mean $=1.06)$, and minor customs obstacles $($ mean $=1.00)$. Senior management spends $10.73 \%$ of their time dealing with government regulations, and $58 \%$ of our sample firms were inspected by tax officials the previous year.

Among the explanatory variables, our key variable, $A F S$, is an indicator variable that equals 1 if a firm's annual financial statements are checked and certified by an external auditor, and 0 otherwise. As shown in Table 1, about $51 \%$ of the surveyed firms choose to have their financial statements audited.

Ten firm-level characteristics are used as control variables in the regressions. The first is firm size. Large firms are linked to fewer business obstacles than small firms, while small firms benefit when growth obstacles are reduced (Schiffer and Weder, 2001; Beck et al., 2005; Cull and $\mathrm{Xu}, 2005$; Knack and $\mathrm{Xu}, 2017$ ). Moreover, firm size tends to be positively related with firm profitability in small to medium-sized enterprises (Papadogonas, T. A., 2007; Doğan, 2013; and Yazdanfar, 2013). ${ }^{13}$ Considering that firm profitability is not directly available from the WBES dataset, including firm size helps to control the effect of firm profitability. As shown in Panel A of Table 1, the mean and median employee numbers (FirmSize) in our sample are 98 and 20, respectively, which indicate the existence of extreme outliers regarding firm size. To alleviate the concern of extreme outliers, we take the logarithm of full-time employees as firm size (Ln_FirmSize).

Because younger firms tend to grow faster than older firms (Dunne et al., 1988) and are more likely to be harassed to pay bribes due to a less-developed relationship with bureaucrats

\footnotetext{
${ }^{13}$ Becker-Blease et al. (2010) argue that there is a reverse U-shape size-profitability relationship in US manufacturing firms. Considering that 50\%, 75\% and 95\% of firms surveyed by WBES have less than 20, 60 and 350 employees, respectively, few firms in our sample may have a firm size more than the optimal point.
} 
(Fisman and Svensson, 2007), we control for firm age (FirmAge). In our sample, the average firm has been in business for about 18 years, and the oldest firm is 340 years old (Table 1, Panel A). ${ }^{14}$ We take the natural logarithm of a firm's age (Ln_FirmAge) to reduce the influence of outliers.

We also control for the work experience of top managers. All things being equal, moreexperienced managers are likely to have more-developed business relationships. Furthermore, experienced managers are likely to know where and how to build connections with key government officials (Bac, 2001). Managerial experience (Experience) is measured as the number of years that the top manager has been working in the same sector. In our sample, the average Experience for the top manager is 17.5 years (Table 1, Panel A).

We further control for ownership structure of the firm. State ownership is believed to be and is often shown in fact to be associated with more political interference. State ownership's political motives (employment and social stability) usually trump profit motives, leading to corrupt dealings (Megginson and Netter, 2001; Beck et al., 2005). We measure government ownership in our analysis with a dummy variable, Government, that equals 1 if the government has a ownership stake in the firm, and 0 otherwise. In our sample, only $1 \%$ of all firms have at least partial government ownership.

In developing countries, foreign-owned firms are more likely to be targeted for harassment by local bureaucrats because they have fewer useful connections than domestic firms. They are also more likely to be harassed in part because they tend to be more profitable (Estrin et al., 2009; Harrison et al., 2014). We control for firm's foreign ownership with a dummy variable, Foreign, that equals 1 if any foreign companies or individuals have an ownership stake in the firm, and 0 otherwise. About $8 \%$ of all firms in our sample have foreign ownership.

Another key variable we control for is competition. Competition increases the risk of forced exits from the market. This spurs effort by firms to stay in business, including building useful business and government connections. Firms facing more-intensive competition tend to experience greater financing obstacles and corruption (Beck et al., 2005). We thus include a dummy variable, Compete, that equals 1 if the firm answered "Yes" to the question: "Does this

\footnotetext{
14 The oldest firm in our sample is a food-manufacturing firm in Jamaica.
} 
establishment compete against unregistered or informal firms?"15 About $50 \%$ of our sample firms believe that they compete against informal firms (see Panel A of Table 1).

We also control for the firm's exporting status and capital expenditures. Firms involved in exporting may be more vulnerable to rent extraction and subject to greater bureaucratic scrutiny and regulation than firms with only local sales (Fisman and Svensson, 2007). Hence, we include a dummy variable denoting whether a firm directly exports (Exporter). We control for capital expenditures, CapitalExpenditure, because capital expenditures likely capture a firm's growth opportunities. A high-growth firm is more likely to be the target of rent extraction, as high-growth firms have more interactions with bureaucrats regarding business licenses and permits and with state-controlled banks for credit. Panel A, Table 1, shows that $17 \%$ of our sample firms are exporters, and $44 \%$ have capital investment.

Finally, we control for firm legal category in the regressions. As noted earlier, listed firms and non-listed firms face very different market and regulatory pressures that shape their financial reporting decisions. Firms registered as limited liability companies also face different accounting and tax rules compared with firms registered as sole proprietorships and partnerships. In this study, firms that report their legal status as a "shareholding company with traded shares" are defined as public firms (Public). Firms that report their legal status as a "shareholding company with nontraded shares" are defined as limited liability companies (Company). Firms whose legal status is reported as a sole proprietorship, a partnership, a limited partnership, or other are defined as "NonCompany". Public and Company are used as control variables in the regressions, while NonCompany is the default category. In our sample, $5 \%$ of the sample firms are Public while $42 \%$ of the firms are Company, and 53\% of the firms are NonCompany (see Panel A, Table 1).

We now turn to measures of country-level control variables. Eight basic macro controls, which are GDP, GDP per capita, GDP growth, inflation, private credit, corruption control, government effectiveness and rule of law, are incorporated in all our regressions. First, we control for key macroeconomics indicators, including the GDP level, GDP per capita, the GDP growth rate, and inflation, as the basic macroeconomic environment influences firm policies and firms' interactions with bureaucrats (as in Beck et al., 2005; Knack and Xu, 2017). Second, country-level

\footnotetext{
${ }^{15}$ Arguably this is not the best measure of competition since it does not capture competition from the formal sector. However, the informal sector accounts for a large share of the economy in developing countries (La Porta and Shleifer, 2014). Moreover, the WBES does not contain better measures.
} 
financial development also plays important roles in determining how firm-level financial information is disseminated and used by various economic agents. As a control for country-level financial/credit market development, we use the ratio of domestic banking credit to the private sector over GDP (PrivateCredit). The mean of PrivateCredit is $38.8 \%$ (see Panel A, Table 1). Third, we include three measures from the World Bank's World Governance Indicators (WGI) database to capture the country-level institutional development. These three measures are corruption control (CorruptionControl), government effectiveness (GovernmentEffectiveness), and the rule of law (RuleofLaw). All three variables range from -2.5 (weak) to +2.5 (strong) and vary widely across our sample countries (see Panel A of Table 1).

Extended sets of macro controls, which are economic freedom, legal origins and culture, are included in our robustness tests. We expect that those controls would help us to further reduce the country-level omitted variable concern, especially the omitted country governance concern. Prior studies show that economic freedom, legal origins, and culture all have significant impacts on country-level corruption and governance (Husted, 1999; Glaeser and Shleifer, 2002; Graeff and Mehlkop, 2003). We therefore include economic freedom measures (GovernmentIntegrity, FinancialFfreedom, and BusinessFreedom), country legal origins (English, Nordic, German, Socialist, and French), and culture measures (PowerDistance, Individualism, UncertaintyAvoidance, and Masculinity). As shown in Panel A of Table 1, these additional macro controls exhibit rich variations across our sample countries.

We also control for country, industry, and year fixed effects in our multivariate regressions. The country dummy holds constant all country-specific factors such as geography, culture, and the basic legal system, which are time-invariant during our sample period. The industry and year dummies further hold constant all industry-specific heterogeneity and worldwide common shocks. These comprehensive controls are useful to address the omitted variable concerns.

\subsection{Univariate Tests}

We first present univariate test results for our key variables between firms with $A F S$ ( $A F S$ firms) and without $A F S$ (non- $A F S$ firms) (see Panel B of Table 1). Relative to non- $A F S$ firms, $A F S$ firms face a significantly higher level of CorruptionObstacle, LicenseObstacle, and CustomsObstacle. Management in AFS firms also spends more time dealing with government regulations and those firms are more likely to be inspected by tax officials. AFS firms are generally 
larger and older, and their top managers are more experienced. They are more likely to have foreign or government ownership, to export, and to invest in fixed assets, but less likely to compete with competitors in informal sectors. The legal status of AFS firms tends to be Public (listed) or Company (non-listed limited liability), instead of NonCompany (sole proprietorship or partnerships). In summary, our univariate tests show that $A F S$ and non- $A F S$ firms differ significantly in corruption obstacles and other firm characteristics, which will be controlled for in the regressions.

\section{[Insert Table 1 about here]}

Before we get to the empirical results, it is important to bear in mind potential danger of over-interpreting the quantitative results for any policy debate. While the qualitative empirical results are informative on the direction of the underlying relationship, the specific quantitative magnitude might hinge on the underlying institutional and other contexts. Hence, strong caution is advised when considering our quantitative estimates in policy debates.

\section{AFS and Corruption Obstacles}

We now investigate the costs associated with the production of $A F S$ regarding government expropriation. The baseline specification is as follows:

$$
\begin{aligned}
& \text { CorruptionObstacle } i j j_{i j}=a+\beta_{1} \text { AFS }_{i j}+\beta_{2} \text { Ln_FirmSize }_{i j}+\beta_{3} \text { Ln_FirmAge }_{i j}+\beta_{4} \text { Experience }_{i j}+\beta_{5} \text { Government }_{i j}+ \\
& \beta_{6} \text { Foreign }_{i j}+\beta_{7} \text { Exporter }_{i j}+\beta_{8} \text { Compete }_{i j}+\beta_{9} \text { CapitalExpenditure }_{i j} \\
&+\beta_{10} \text { Public }_{i j}+\beta_{11} \text { Company }_{i j}+\theta^{\prime} \text { Country Controls }_{j}+\varepsilon_{i j}
\end{aligned}
$$

We expect $\beta_{1}$, the coefficient of $A F S$, to be positive and significant, as we hypothesize that the production and disclosure of $A F S$ increases the potential of government expropriation.

The empirical results are presented in Table 3. Columns (1) and (3) report the OLS/LPM regression results and columns (2) and (4) report the Ordered Probit results. Country fixed effects are only included in columns (3) and (4), while country-level macro controls and industry and year fixed effects are included in all regressions. Consistent with our hypothesis, the coefficients of $A F S, \beta_{1}$, are positive and significant at the conventional level in all four regressions. These results constitute our baseline finding that the production of $A F S$ is linked to higher-level corruption obstacles faced by the firm. We note that once country fixed effects are included in the OLS 
regressions, the magnitude of the AFS coefficient becomes smaller. Specifically, when a firm shift its audting status from 0 to 1 , its reported corruption obstacle may increase by 0.157 when country fixed effects are not included, which is a $9 \%(0.157 / 1.71)$ increase in its reported corruption obstacles considering that the average corruption obstacles in our sample is 1.71 . When country fixed effects are included, a shift in audting status from 0 to 1 may increase a firm's reported corruption obstacles by 0.046 , a $3 \%(0.157 / 1.71)$ increase.

How other firm characteristics affect corruption obstacles is also interesting. Perceived corruption obstacles are lower in firms with government ownership. Firms with government ownership probably have stronger political connections compared to firms without government ownership. It might be that managers in state-owned firms know "who to call" to get things done (Bac, 2001). Perceived corruption obstacles are higher for exporters, which not surprising given that exporting firms have to go through a lot bureaucratic red tape to obtain export licenses in developing countries, which increases their vulnerability to government expropriation (Murphy et al., 1993, Svensson, 2005). Perceived corruption obstacles are higher for firms that compete with informal businesses. Informal businesses are partially immune from government harassment because they avoid formal registration and become invisible to the government (Johnson et al., 1998).

As a robustness test, we replace CorruptionObstacle with CorruptionDummy in Equation (2) and rerun all the four regressions. AFS continues to be positively and significantly related to Corruption Dummy. ${ }^{16}$

\section{[Insert Table 2 about here]}

\section{Potential Endogeneity}

Potential reverse causality in the $A F S-C O$ relationship and omitted variables in our regression specifications may bias our baseline results reported in Table 2. As shown in Johnson et al. (1998), higher corruption drives more firms to go underground (becoming part of the informal economy). Durnev et al. (2009) and Durnev and Fauver (2011) further show that high government expropriation risk leads to low transparency. This reverse causality would yield an underestimated $A F S$ effect: the real $A F S$ effect on firm-level corruption obstacles is more pronounced than the OLS estimate. Hence, the reverse causality documented in the above studies should strengthen our

\footnotetext{
${ }^{16}$ For brevity, we report the results in Internet Appendix Table IA1.
} 
confidence in the OLS findings. We also recognize the issue of omitted variables. As previously discussed in Section 3.2, ten firm-level controls (including AFS), eight country-level controls, and country, industry, and year fixed effects are included in our regressions. We realize that these controls help alleviate some concerns about omitted variables, but the concerns remain, nevertheless.

To establish a causal effect that $A F S$ leads to more firm-level corruption obstacles, we need to show the counterfactual that, had the firm not produced and disclosed audited financial statements, it would have been subject to less harassment by bureaucrats. However, the WBES data for financial reporting practices are not randomly assigned among firms. In the absence of a random assignment, one can identify the causal effects by relying on one of the three common empirical strategies - IV techniques, panel datasets, or natural experiments (such as policy shocks) that produce exogenous variations. We discuss our regression results using the above three strategies in Sections 5.1, 5.2, and 5.3, respectively. Furthermore, as a qualitative robustness check, in Section 5.4, we conduct a semi-structured survey of business owners to gauge their experiences and thoughts concerning financial disclosure on corruption obstacles in practice.

\subsection{Analysis}

We use the country-industry-year average probability of $A F S$ (AFS_CIY) as an IV for AFS. $A F S \_C I Y$, which reflects that the financial transparency environment a firm faces should positively affect a firm's external auditing decision but should not directly affect a firm's perceived corruption obstacles. Similar firms controls as specified in Eq (1), industry and year fixed effects are included in our two-stage least squares (2SLS) regressions. Results with various country level controls are reported in different columns in Table 3.

First, we include the same set of macro controls in our regressions as we do in Table 2, and report the results in Table 3, Columns (1) and (5). In the first stage (Column 1), AFS_CIY is positively and significantly related with AFS. In the second stage (Column 5), the predicted AFS is positively and significantly related with $C O$.

Second, we extend our macro controls to alleviate the concern that country-level omitted variables, especially omitted country governance or institution variables, may bias our OLS estimation. We therefore include economic freedom measures (GovernmentIntegrity, FinancialFreedom, and BusinessFreedom) and country legal origins (English, Nordic, German, 
Socialist, and French) in the 2SLS, and report the results in Table 3, Columns (2) and (6). Additional culture measures (PowerDistance, Individualism, UncertaintyAvoidance and Masculinity) are included the 2SLS regressions with results reported in Columns (3) and (7). Due to data unavailability, including culture measures reduces the number of observations by approximately $1 / 3$. After including this extensive set of macro level variables, $A F S \_C I Y$ continues to be positively and significantly related with AFS (Columns 2 and 3), and the predicted AFS continues to be positively and significantly related with $C O$ (Columns 6 and 7).

Third, we add country fixed effects in addition to basic macro variables in the 2SLS regressions with results reported in Table 3, Columns (4) and (8). The $1^{\text {st }}$ stage result remains positive and significant, while the $2^{\text {nd }}$ stage result is still positive but statistically insignificant at the $10 \%$ level $\left(\mathrm{t}\right.$-statistic=1.45). We acknowledge that the instrumental variable we use, $A F S \_C I Y$, which is calculated as the country-industry-year average probability of $A F S$, has limited variation when country, industry and year fixed effects are all included in the regressions. We also note that once country fixed effects are included in the 2SLS regressions, the magnitude of the coefficient becomes smaller, a pattern similar to the results in Table 2.

In sum, Table 3 shows that our results are robust with the inclusion of an extensive list of country-level governance and institution variables, which helps to alleviate the concern that omitted country governance factors may drive our results. We note that the main purpose of the 2SLS analysis is to provide supporting evidence for the results of the OLS analysis, (in particular, the sign of the coefficients of interest rather than its quantitative value), and we suggest the readers to interpret the magnitude of these IV estimates with caution.

\section{[Insert Table 3 about here]}

\subsection{Panel Analysis}

The World Bank surveyed most of the countries a few times in different years, so within each country, some firms are surveyed twice. We use the idenifier provided by the World Bank to find these firms and form a panel dataset. With the panel data, we can control for firm fixed effects, hence separating the impacts of the firm-level time-invariant omitted variables.

Table 4 reports the panel regression results. Firm fixed effects are included in all regressions. Industry fixed effects are only included in Columns (3) and (4) since the majority of 
firms do not switch their industry between the two surveys, and controlling for firm fixed effects renders industry fixed effects unimportant. Columns (1) and (3) report the whole panel dataset results, while Columns (2) and (4) report the subsample results for firms that changed AFS status. Again, we find that $A F S$ is positively and significantly related to corruption obstacles in all regressions.

\section{[Insert Table 4 about here]}

\subsection{Regression Discontinuity Design Analysis}

We perform a regression discontinuity design (RDD) analysis using the mandatory auditing requirements issued by certain countries. ${ }^{17}$ For this analysis, we collected data for 41 countries that use the number of employees as one of the mandatory auditing thresholds (see Internet Appendix Table IA3). Two examples are presented below: ${ }^{18}$

Greece: Greece's accounting Law 4449/2017 stipulates that "Under the law, all public interest entities and all companies that meet two of the following criteria for two consecutive years are subject to mandatory statutory audits: (i) total assets of EU 4,000,000; (ii) net turnover of EU 8,000,000; and (iii) average employees of 50 for the year."

Hungary: "Companies surpassing both of the following thresholds must undergo a statutory audit: (i) the annual net sales (calculated for the period of one year) exceed Hungarian forint (HUF) 300 million on the average of the two financial years preceding the financial year under review and (ii) the average number of people employed by the undertaking exceed 50 people on the average of the two financial years preceding the financial year under review."

The laws indicate that a firm may trigger the mandatory auditing requirement if its assets, revenue, or number of employees exceed certain thresholds. We hand-collect the country-level data of mandatory auditing requirements by searching all countries surveyed by the World Bank regarding their accounting and auditing laws. Since assets are not available in the WBES, revenues

\footnotetext{
${ }^{17}$ A partial list of recent studies using this technique to examine various corporate decisions includes Cunat et al. (2012, 2020), Boone and White (2015), Becht et al. (2016), Malenko and Shen (2016), Focke et al. (2017), and Li et al. (2018).

${ }^{18}$ For more details, see https://www.ifac.org/about-ifac/membership/country/greece.
} 
reported by each firm are often rounded to the nearest thousands or millions; only the number of employees is reported relatively precisely in the WBES (Cheng et al., 2020). We hence choose the employee thresholds required by each country as the cutoff points used in our RDD analysis. The discrete nature of the threshold provides us an opportunity to investigate firms with employees right above or below the threshold. ${ }^{19}$

However, the requirement of triggering multiple threholds limits our ability to precisely estimate which firms should be audited because of the dataset coverage. We argue that a higherthan-threshold employee number only increases the probability that the firm needs to be audited when the asset measure is unavailable and the revenue measure is imprecise. Moreover, the majority of the countries in our sample are developing economies with weak institutions. Firms who satify all auditing requirements may still choose not to reveal its financial statements if the countries' accounting/auditing law is not properly enforced.

Another limitation we face is the percent of firms that are required by law to be audited. Only $23 \%$ of firms are in countries with a clearly specified employee related auditing requirement. Within these countries, $21 \%$ of the firms have employees above the threshold, representing about only $5 \%$ of our full sample. We find that, $72 \%$ of these above-employee-threshold firms are audited, indicating that either some firms do not meet two or more auditing thresholds, or some firms simply choose not to be audited if non-compliance is not associated with a substantial punishment. On the other side, $41 \%$ of these below-employee-threshold firms are audited. Therefore, for a super majority of firms in our sample, firms still choose whether to produce audited financial statements.

The key assumption of a valid RDD for causal interpretation is that agents cannot precisely manipulate the running variable, which is the number of employees in our setting. We conjecture that if firms perceive producing audited financial statements is associated with higher corruption obstacles, they may try to stay right below the mandatory disclosure threshold to avoid having their financial statements audited. To formally test whether firms manipulate number of employees around the threshold, we test the null hypothesis of no discontinuity at the number of employees around the auditing threshold (McCrary, 2008). The test strongly rejects the null hypothesis of no discontinuity regardless of alternative bandwidths and the order of the local-polynomial. We plot the density function in Figure 1 and report the manipulation test results in Table 5. The $\mathrm{x}$-axis

\footnotetext{
${ }^{19}$ As shown in Table IA2, the thresholds range from 10 employees in Tunisia to 1,000 in Sri Lanka.
} 
measure used in Figure 1, Distance, equals the number of employees minus the threshold. Visual inspection of Figure 1 reveals clear evidence of firms trying to avoid triggering the disclosure threshold: there is a distinct discontinuity of the density function at the number of employee threshold due to a cluster of firms stay right below the threshold.

\section{[Insert Figure 1 about here]}

\section{[Insert Table 5 about here]}

Since we find strong evidence that firms do manipulate the number of employees, we are not able to draw a definite conclusion regarding causality because firms are not randomly distributed around the threshold. We nevertheless proceed to test whether the perceived corruption obstacles are different around the threshold. Figure 2 plots local sample means (i.e., the dots in the graph) of corruption obstacles using nonoverlapping evenly spaced bins on each side of the number of employees threshhold. The solid lines are based on local linear regression model (Panel A) and smoothed quadratic polynomial model (Panel B) estimated separately on the two sides of the threshold. The plot shows a discontinuous jump in corruption obstacle right at the threshold: firms with number of employees right above (below) the auditing threshold have higher (lower) corruption obstacles. We further report the regression discontinuity (RD) estimates (with and without controls) for alternative bandwidths in Appendix 3. Consistent with Figure 2, we find that overall, RD estimates are positive, although some of them are not statistically significant, depending on the bandwidth used and whether the confidence intervals are bias-corrected (Calonico et al., 2014).

\section{[Insert Figure 2 about here]}

Overall, although we are not able to draw causal inference based on our RD estimates because it appears that firms are not randomly distributed around the auditing threshold of the number of employees, we think this analysis provides us interesting supporting evidence that suggests firms perceive that it is costly to reveal their financial information by producing audited financial statements.

\subsection{Evidence from a Survey of Entrepreneurs}


In the previous sections, we document a positive relationship between $A F S$ and $\mathrm{CO}$. We also provide some evidence of causality in the relation. To directly understand how financial disclosure affects corruption obstacles, we conducted a semi-structured survey of entrepreneurs in developing countries. The survey was qualitative in nature, as opposed to more structured ones that produce data for empirical analysis. The goal is to gain insights directly from entrepreneurs concerning the relation between financial disclosure and corruption. In other words, we want to know whether our empirical findings are qualitatively consistent with what happens "on the ground."

We prepared three open-ended questions (See Table 6, Panel A) to elicit thoughts and experiences from business insiders concerning whether their firms are negatively affected by corruption (Q1), whether and how financial disclosure is linked to corruption (Q2 and Q2a), and whether their firms take any specific measures to control financial disclosure to limit corruptionrelated costs (Q3). Q2 and Q2a were designed to qualitatively address our main hypothesis that more financial disclosure leads to higher corruption-related costs for the firm. Q3 was designed to provide a qualitative robustness check, that is, if more disclosure leads to more corruption obstacles, then entrepreneurs would take measures to control information disclosure. We carried out two surveys: one involved face-to-face interviews of business executives at an international tradeshow in Las Vegas, and the other involved written surveys of business owners in China.

\subsubsection{Interviews at the SupplySide West Trade Show}

SupplySide West is an annual trade show held at the Mandalay Bay Hotel in Las Vegas, Nevada. The 2017 exhibition, held September 26-30, 2017, provided us with a suitable setting to conduct face-to-face interviews of entrepreneurs. Over 1,000 exhibitors and 15,000 participants from 30 countries attended the 2017 exhibition. One co-author and three Ph.D. students attended the trade show from September 28 to September 30. Our strategy was to seek exhibitors from developing countries, wait for a quiet time when no other attendees were actively engaging the exhibitors, and then approach the person operating the exhibition booth. We first identified ourselves ("We are researchers from the xxx university") and inquired about the person's position in the company. If the person self-identified as a senior position holder (owner, general manager, or senior VP), then we conveyed the purpose of our survey ("We are doing a research project and would greatly appreciate if we can have 15-20 minutes of your time to ask a few questions"). We 
assured anonymity ("The identities of you and your firm will not appear in our notes nor our research report"). If the person identified himself or herself as an assistant, a secretary, or "just a marketing person," then we thanked him or her and moved on to the next booth.

In total, we were able to initiate 51 interviews at the trade show over two days, with 41 executives from China, five from India, three from Mexico, one from Argentina, and one from Taiwan. However, among the 51 interviews, only nine produced useful responses (Table 6, Panel B1). The useful ones are those in which all the questions were answered with genuine effort.

\subsubsection{Survey of Entrepreneurs}

Due to the limited success of our face-to-face interviews at the trade show, we carried out a targeted written survey of business owners in China. Instead of "cold calls," which would possibly yield even worse outcomes than our face-to-face interviews, we surveyed business owners personally known by at least of one of the co-authors. We also asked each of our business owner friends to distribute the survey to a few of his or her entrepreneur friends. We emphasized anonymity, and also stressed that their actual experiences and true thoughts on the corruptionrelated questionnaires would be the most helpful. After distributing the surveys, we waited for two weeks then followed up with emails and phone calls. At the end of one month, 17 surveys were returned. Among the returned surveys, nine are considered useful in that all questions were answered with genuine effort (Table 6, Panel B2). Between the face-to-face interviews and the written surveys, we obtained 18 useful surveys.

\section{[Insert Table 6 about here]}

\subsubsection{Survey Results}

As mentioned earlier, the interviews and surveys were not meant to produce data for statistical analysis. Instead, we aim to provide direct evidence by asking business owners their true thoughts on how financial disclosure affects corruption obstacles their firms face. Out of 18 useful surveys, 13 business owners (72\%) confirmed that their businesses have been negatively affected by corruption $(\mathrm{Q} 1)$.

Regarding Q2, that is, whether more financial disclosure leads to higher chances of corruption obstacles in their firms, in 11 out of the 18 useful surveys (61\%), entrepreneurs responded that the production of their companies' financial information increases corruption 
obstacles. The majority of the entrepreneurs surveyed (10 out of 18, or 56\%) indicated that their firms take measures to restrict financial information disclosure to minimize corruption-related costs (Q3).

In summary, the results from the surveys and interviews provide qualitative support for our main finding, that is, what we document in the paper is qualitatively consistent with what happens "on the ground." Explicitly, the majority of the entrepreneurs surveyed confirm there is a link between financial disclosure and corruption obstacles their firms face. The majority of them further state that more financial disclosure could lead to "more troubles" for the firms.

Taking together, the results from these endogeneity strategies reported in Tables 3, 4, and 5 provide support for our baseline results and suggest that the production and disclosure of detailed and credible financial information leads to a higher level of harassment by rent-seeking bureaucrats in private firms across a large number of developing economies.

\section{Specific Measures of Corruption Obstacles}

In our baseline analysis, we use CorruptionObstacle as an aggregate measure of perceived corruption obstacles faced by the firm. As robustness checks, we employ several specific measures of obstacles arising from firms' direct interactions with government officials. If $A F S$ leads to more exposure to government expropriation, we are likely to observe an increase in harassment in places where firms' interactions with bureaucrats take place, and sometimes those interactions are unavoidable. We hence examine obstacles encountered by firms when applying for business licenses and permits (LicenseObstacle) or when dealing with customs and trade regulations (CustomsObstacle). ${ }^{20}$

We also argue that disclosing more financial information would entice bureaucrats from various government agencies to use their authority to extract bribes. Specifically, tax inspectors in developing countries may consider tax inspections as good opportunities to solicit bribes (Alm et al., 2016). Hence, we conjecture that $A F S$ will cause senior management to spend more time dealing with government regulations (TimeonGovernment) and increase the odds of being inspected by tax officials (TaxInspection), thereby providing more rent-seeking opportunities.

\footnotetext{
${ }^{20}$ Svensson (2005) once interviewed a successful Thai CEO and the topic was corruption in the foreign trade sector. The CEO exclaimed, "I hope to be reborn as a customs official." Svensson (2005) could only conclude that corruption at customs is severe.
} 
As shown in Table 7, the coefficient of $A F S$ is positive and significant across all four models, with or without country fixed effects. These results lend further support to our thesis in that they point to specific channels through which corrupt bureaucrats could use the disclosed financial information to increase their rent-seeking opportunities.

\section{[Insert Table 7 about here]}

\section{The Role of Institutional Development}

So far, we have assumed that $A F S$ has a homogeneous effect on corruption obstacles across countries. But this effect likely hinges on the underlying institutions (Stulz, 2005; Durnev and Guriev, 2011). A large volume of literature has documented a direct positive relationship between a country's institutional development and economic growth at the country level as well as at the firm level (Knack and Keefer, 1995; La Porta et al., 2000; Beck et al., 2000; Acemoglu et al., 2001; Acemoglu and Johnson, 2005; Dyck and Zingales, 2004; Beck et al., 2005, Beck et al., 2006, Doidge et al., 2007, Harrison et al., 2014, among others). Since developing countries are characterized by low-quality institutions, a high level of public corruption, and low contracting efficiency, firms wary of government expropriation, unenforceable contracts, or unfair competitions will adopt less-than-optimal financial reporting practices. Therefore, we conjecture that a country's institution quality plays an important role in the relation between $A F S$ and the degree of harassment by bureaucrats at the firm-level.

To measure country-level institutional quality, we employ three measures from Worldwide Governance Indicators (CorruptionControl, GovernmentEffectiveness, and RuleofLaw). These measures are estimates of a country's overall institutional ability to control public corruption. Higher values indicate better institutional quality and less government expropriation (see Appendix 2 for descriptions of these indices). As shown in Panel A of Table 1, these indices vary widely across our sample countries.

We now examine how the effect of $A F S$ on corruption obstacles depends on the national level of institutional developments. We add to Equation (1) three interactions, AFS*CorruptionControl, AFS* GovernmentEffectiveness, or AFS*RuleofLaw, and re-estimate the equation with OLS regressions in Table 8.

The coefficients of all three interaction terms are negative and significant. Thus, a country's corruption control, government effectiveness, and rule of law all play an important role in 
moderating the $A F S$-CO relation. In other words, when a country's governance improves, the cost of government expropriation associated with $A F S$ decreases. These results suggest that enhancing the country-level institutional quality can effectively constrain bureaucrats' rent-seeking and encourage firms' information disclosure.

\section{[Insert Table 8 about here]}

\section{Conclusions}

Using WBES data for about 150,000 firms in 143 developing countries from 2006-2019, we study financial reporting practices and their consequences. We focus on potential costs associated with $A F S$ and document that $A F S$ firms are associated with higher levels of corruption obstacles than non-AFS firms. Our results hold after various endogeneity tests and robustness checks. We further document that country-level institutional development has an important impact on the AFS-CO relationship.

Our study contributes to the literature by providing novel empirical evidence that $A F S$ is linked to higher corruption obstacles at the firm level. This finding demonstrates that increased financial transparency bears important costs in exposing the firm to government expropriation, as a rent-seeking bureaucrat utilizes the disclosed financials to maximize the level of harassment (Bliss and Tella, 1997; Svensson, 2003; and Fisman and Svensson, 2007). The dark side of exposing firms to government expropriation is rarely explored empirically in the literature (Leuz and Wysocki, 2008), and our study usefully fills this literature gap. Our empirical findings are also supported by the survey and interview responses we obtained from entrepreneurs who operate businesses in developing countries.

Our paper also contributes by finding that country-level institution quality plays an essential role in the relationship between financial reporting practices and firm-level business obstacles faced by private firms in developing countries. This finding nicely illustrates the complementary relationship between financial disclosure and institutional background, which is also underexplored in the literature but emphasized by Leuz and Wysocki (2008) in their survey.

Our paper illustrates that increased firm financial transparency via the production of detailed and credible financial information, is related to the increased risk of government expropriation. As firm financial information becomes more readily available, government expropriations (i.e., corruption obstacles) become more severe, especially in countries with poor institutional quality. The 
results thus support Acemoglu and Johnson (2005) on the overwhelming importance of constraining government expropriation.

Finally, our results have policy implications. Specifically, as shown in Table IA3, more developing countries have started to adopt rules that require firms to audit financial statements under the implicit assumption that in general, information disclosure benefits firms. However, our findings that show a potential dark side of producing audited financial statements and imply that not all these country-level mandatory disclosure requirements unambiguously benefit firms, especially if the country has weak institution quality. Indeed, our evidence of firms choosing not to trigger the audit requirement by limiting the number of their employees suggests that firms are willing to forgo some growth opportunities to avoid potential costs associated with producing audited financial statements.

Our paper represents a step forward in understanding private firms' financial disclosure decisions and their consequences in developing countries. As more data becomes available, especially firm-level panel data on investment returns and change of ownership/investor types, scholars can help advance this understanding in future research in two important areas. First, given that the literature provides mixed evidence on how corruption affects returns to investment and investment efficiency (e.g., Campos et al., 1999; Cumming et al., 2010; O’Toole and Tarp, 2014; Zheng and Xiao, 2020), it would be helpful to examine the impact of the disclosure-induced cost of corruption on firm growth and investment efficiency, as this empirical evidence will help answer questions concerning the net impact of information transparency when firms operate in corrupting environment. Another interesting question would be that when governance fails at the country level, are there alternative governance mechanisms that can alleviate the negative impact? Existing literature suggests that active private equity fund managers that bring about organizational change in their investees can alleviate the expected costs of corruption (e.g., Cressy et al., 2007; Cumming, 2008; Cumming et al., 2010). Future research may investigate whether and how active institutional investors affect the costs and benefits of information disclosure in countries with different levels of corruption. 


\section{References}

Acemoglu, D., Johnson, S., 2005. Unbundling institutions. Journal of Political Economy, 113(5), 949-995.

Acemoglu, D., Johnson, S., Robinson, J.A., 2001. The colonial origins of comparative development: An empirical investigation. American Economic Review, 91(5), 1369-1401.

Admati, A.R., Pfleiderer, P., 2000. Forcing firms to talk: Financial disclosure regulation and externalities. Review of Financial Studies, 13(3), 479-519.

Akerlof, G., 1970. The markets for lemons: Quality uncertainty and the market mechanism. Quarterly Journal of Economics, 84, 488-500.

Akins, B., Dou, Y., Ng, J., 2017. Corruption in bank lending: The role of timely loan loss recognition. Journal of Accounting and Economics, 63(2-3), 454-478.

Allee, K.D., Yohn, T.L., 2009. The demand for financial statements in an unregulated environment: An examination of the production and use of financial statements by privately held small businesses. Accounting Review, 84(1), 1-25.

Alm, J., Martinez-Vazquez, J., McClellan, C., 2016. Corruption and firm tax evasion. Journal of Economic Behavior \& Organization, 124, 146-163.

Bac, M., 2001. Corruption, connections and transparency: Does a better screen imply a better scene? Public Choice, 107(1-2), 87-96.

Bardhan, P., 1997. Corruption and development: A review of issues. Journal of Economic Literature, 35(3), 13201346.

Barth, J.R., Lin, C., Lin, P., Song, F.M., 2009. Corruption in bank lending to firms: Cross-country micro evidence on the beneficial role of competition and information sharing. Journal of Financial Economics, 91(3), 361388.

Becht, M., Polo, A,. Rossi, S., 2016. Does mandatory shareholder voting prevent bad acquisitions?. The Review of financial studies, 29(11), 3035-3067.

Beck, T., Demirgüç-Kunt, A., Levine, R., 2006. Bank supervision and corruption in lending. Journal of Monetary Economics, 53(8), 2131-2163.

Beck, T., Demirgüç-Kunt, A.S.L.I., Maksimovic, V., 2005. Financial and legal constraints to growth: Does firm size matter? Journal of Finance, 60(1), 137-177.

Beck, T., Levine, R., Loayza, N., 2000. Finance and the Sources of Growth. Journal of Financial Economics, 58(12), 261-300.

Becker-Blease, J. R., Kaen, F. R., Etebari, A., Baumann, H., 2010. Employees, firm size and profitability of US manufacturing industries. Investment Management and Financial Innovations.

Berger, P.G., Minnis, M., Sutherland, A., 2017. Commercial lending concentration and bank expertise: Evidence from borrower financial statements. Journal of Accounting and Economics, 64(2-3), 253-277.

Berger, P.G., Hann, R.N., 2007. Segment profitability and the proprietary and agency costs of disclosure. Accounting Review, 82(4), 869-906.

Bliss, C., Tella, R.D., 1997. Does competition kill corruption? Journal of Political Economy, 105(5), 1001-1023.

Boone, A.L.,White, J.T., 2015. The effect of institutional ownership on firm transparency and information production. Journal of Financial Economics, 117(3), 508-533. 
Bushman, R.M., Smith, A., 2003. Transparency, financial accounting information, and corporate governance. Economic Policy Review, 9(Apr), 65-87.

Cadot, O., 1987. Corruption as a Gamble. Journal of Public Economics, 33(2), 223-244.

Cai, H., Fang, H., Xu, L.C., 2011. Eat, drink, firms, government: An investigation of corruption from the entertainment and travel costs of Chinese firms. The Journal of Law and Economics, 54(1), 55-78.

Calonico, S., Cattaneo, M. D., Titiunik, R., 2014. Robust data-driven inference in the regression-discontinuity design. The Stata Journal, 14(4), 909-946.

Campos, J. E., Lien, D., Pradhan, S., 1999. The impact of corruption on investment: Predictability matters. World development, 27(6), 1059-1067.

Cassar, G., 2011. Discussion of the value of financial statement verification in debt financing: Evidence from private US firms. Journal of Accounting Research, 49(2), 507-528.

Chen, F., Hope, O.K., Li, Q., Wang, X., 2011. Financial reporting quality and investment efficiency of private firms in emerging markets. Accounting Review, 86(4), 1255-1288.

Cheng, C.A., Sun, W., Ye, K., Zhang, N., 2020. The effect of auditing on promoting exports: Evidence from private firms in emerging markets. Management Science, 66(4), 1692-1716.

Clarke, G.R., Xu, L.C., 2004. Privatization, competition, and corruption: How characteristics of bribe takers and payers affect bribes to utilities. Journal of Public Economics, 88(9-10), 2067-2097.

Cressy, R., Munari, F., Malipiero, A., 2007. Playing to their strengths? Evidence that specialization in the private equity industry confers competitive advantage. Journal of Corporate Finance, 13(4), 647-669.

Cumming, D., 2008. Contracts and exits in venture capital finance. The Review of Financial Studies, 21(5), 19471982.

Cumming, D., Fleming, G., Johan, S., Takeuchi, M., 2010. Legal Protection, Corruption and Private Equity Returns in Asia. Journal of Business Ethics, 95, 173-193.

Cuñat, V., Gine, M., Guadalupe, M., 2012. The vote is cast: The effect of corporate governance on shareholder value. The Journal of Finance, 67(5), 1943-1977.

Cuñat, V., Giné, M., Guadalupe, M., 2020. Price and Probability: Decomposing the Takeover Effects of AntiTakeover Provisions. The Journal of Finance, 75, pp.2591-2629.

Cull, R., Xu, L.C., 2005. Institutions, ownership, and finance: The determinants of profit reinvestment among Chinese firms. Journal of Financial Economics, 77(1), 117-146.

DeAngelo, L.E., 1988. Managerial competition, information costs, and corporate governance: The use of accounting performance measures in proxy contests. Journal of Accounting and Economics, 10(1), 3-36.

DeFond, M., Zhang, J., 2014. A review of archival auditing research. Journal of Accounting and Economics, 58(2-3), 275-326.

Diamond, D.W., 1985. Optimal release of information by firms. Journal of Finance, 40(4), 1071-1094.

Doidge, C., Karolyi, G.A., Stulz, R.M., 2007. Why do countries matter so much for corporate governance? Journal of Financial Economics, 86(1), 1-39.

Doğan, M., 2013. Does firm size affect the firm profitability? Evidence from Turkey. Research Journal of Finance and Accounting, 4(4), 53-59.

Dunne, T., Roberts, M.J., Samuelson, L., 1988. Patterns of firm entry and exit in US manufacturing industries. RAND Journal of Economics, 495-515. 
Durnev, A., Fauver, L., 2011, November. Stealing from thieves: Expropriation risk, firm governance, and performance. In 2nd Annual Conference on Empirical Legal Studies Paper.

Durnev, A., Guriev, S., 2011. Expropriation risk and firm growth: A corporate transparency channel. Available at SSRN 1320966.

Durnev, A., Errunza, V., Molchanov, A., 2009. Property rights protection, corporate transparency, and growth. Journal of International Business Studies, 40(9), 1533-1562.

Dyck, A., Zingales, L., 2004. Private benefits of control: An international comparison. Journal of Finance, 59(2), 537-600.

Estrin, S., Hanousek, J., Kocenda, E., Svejnar, J., 2009. The effects of privatization and ownership in transition economies. Journal of Economic Literature, 47(3), 699-728.

Fan, J.P., Wong, T.J., 2005. Do external auditors perform a corporate governance role in emerging markets? Evidence from East Asia. Journal of Accounting Research, 43(1), 35-72.

Fisman, R., Svensson, J., 2007. Are corruption and taxation really harmful to growth? Firm level evidence. Journal of Development Economics, 83(1), 63-75.

Focke, F., Maug, E., Niessen-Ruenzi, A., 2017. The impact of firm prestige on executive compensation. Journal of Financial Economics, 123(2), 313-336.

Francis, J.R., Khurana, I.K., Martin, X., Pereira, R., 2011. The relative importance of firm incentives versus country factors in the demand for assurance services by private entities. Contemporary Accounting Research, 28(2), 487-516.

Glaeser, E. L., Shleifer, A., 2002. Legal origins. The Quarterly Journal of Economics, 117(4), 1193-1229.

Graeff, P., Mehlkop, G., 2003. The impact of economic freedom on corruption: different patterns for rich and poor countries. European Journal of Political Economy, 19(3), 605-620.

Guedhami, O., Pittman, J.A., Saffar, W., 2009. Auditor choice in privatized firms: Empirical evidence on the role of state and foreign owners. Journal of Accounting and Economics, 48(2-3), 151-171.

Guedhami, O., Pittman, J.A., 2006. Ownership concentration in privatized firms: The role of disclosure standards, auditor choice, and auditing infrastructure. Journal of Accounting Research, 44(5), 889-929.

Guo, R.J., Lev, B., Zhou, N., 2004. Competitive costs of disclosure by biotech IPOs. Journal of Accounting Research, 42(2), 319-355.

Harrison, A.E., Lin, J.Y., Xu, L.C., 2014. Explaining Africa’s (dis)advantage. World Development, 63, 59-77.

Hope, O.K., Thomas, W., Vyas, D., 2011. Financial credibility, ownership, and financing constraints in private firms. Journal of International Business Studies, 42(7), 935-957.

Hughes, J.S., Liu, J., Liu, J., 2007. Information asymmetry, diversification, and cost of capital. Accounting Review, 82(3), 705-729.

Husted, B. W., 1999. Wealth, culture, and corruption. Journal of international business studies, 30(2), 339-359.

Johnson, S., Kaufmann, D., Zoido-Lobaton, P., 1998. Regulatory discretion and the unofficial economy. American Economic Review, 88(2), 387-392.

Khurana, I.K., Pereira, R., Martin, X., 2006. Firm growth and disclosure: An empirical analysis. Journal of Financial and Quantitative Analysis, 357-380.

Knack, S., Keefer, P., 1995. Institutions and economic performance: cross-country tests using alternative institutional measures. Economics \& Politics, 7(3), 207-227. 
Knack, S., Xu, L.C., 2017. Unbundling institutions for external finance: Worldwide firm-level evidence. Journal of Corporate Finance, 44, 215-232.

La Porta, R., Lopez-de-Silanes, F., Shleifer, A., Vishny, R., 1999. The quality of government. The Journal of Law, Economics, and Organization, 15(1), 222-279.

La Porta, R., Lopez-de-Silanes, F., Shleifer, A., Vishny, R., 2000. Investor protection and corporate governance. Journal of Financial Economics, 58(1-2), 3-27.

La Porta, R., Shleifer, A., 2014. Informality and development. Journal of Economic Perspectives, 28(3), 109-126.

Lambert, R., Leuz, C., Verrecchia, R.E., 2007. Accounting information, disclosure, and the cost of capital. Journal of Accounting Research, 45(2), 385-420.

Lemmon, M.L., Lins, K.V., 2003. Ownership structure, corporate governance, and firm value: Evidence from the East Asian financial crisis. Journal of Finance, 58(4), 1445-1468.

Leuz, C., Wysocki, P.D., 2008. Economic consequences of financial reporting and disclosure regulation: A review and suggestions for future research. Available at SSRN 1105398.

Leuz, C., Verrecchia, R.E., 2000. The economic consequences of increased disclosure. Journal of Accounting Research, 91-124.

Li, K., Liu, T., Wu, J., 2018. Vote avoidance and shareholder voting in mergers and acquisitions. The Review of Financial Studies, 31(8), 3176-3211.

Li, H., Xu, L.C., Zou, H.F., 2000. Corruption, income distribution, and growth. Economics \& Politics, 12(2), 155182.

Malenko, N., Shen, Y., 2016. The role of proxy advisory firms: Evidence from a regression-discontinuity design. The Review of Financial Studies, 29(12), 3394-3427.

Mauro, P., 1995. Corruption and growth. Quarterly Journal of Economics, 110(3), 681-712.

McCrary, J., 2008. Manipulation of the running variable in the regression discontinuity design: A density test. Journal of Econometrics, 142(2), 698-714.

Megginson, W.L., Netter, J.M., 2001. From state to market: A survey of empirical studies on privatization. Journal of Economic Literature, 39(2), 321-389.

Minnis, M., Sutherland, A., 2017. Financial statements as monitoring mechanisms: Evidence from small commercial loans. Journal of Accounting Research, 55(1), 197-233.

Minnis, M., 2011. The value of financial statement verification in debt financing: Evidence from private US firms. Journal of Accounting Research, 49(2), 457-506.

Murphy, K.M., Shleifer, A., Vishny, R.W., 1993. Why is rent-seeking so costly to growth? American Economic Review, 83(2), 409-414.

Olken, B. A., Pande, R., 2012. Corruption in developing countries. Annu. Rev. Econ., 4(1), 479-509.

O'Toole, C. M., Tarp, F., 2014. Corruption and the efficiency of capital investment in developing countries. Journal of International Development, 26(5), 567-597.

Papadogonas, T.A., 2007. The financial performance of large and small firms: evidence from Greece. International Journal of Financial Services Management, 2(1-2), 14-20.

Peisakhin, L., 2012. Transparency and corruption: Evidence from India. The Journal of Law and Economics, 55(1), 129-149.

Rose-Ackerman, S., 1975. The economics of corruption. Journal of Public Economics, 4(2), 187-203. 
Schiffer, M., Weder, B., 2001. Firm size and the business environment: worldwide survey results (Vol. 43). World Bank Publications.

Shleifer, A., Vishny, R.W., 1994. Politicians and firms. The quarterly journal of economics, 109(4), 995-1025.

Stulz, R.M., 2005. The limits of financial globalization. Journal of Finance, 60(4), 1595-1638.

Svensson, J., 2005. Eight questions about corruption. Journal of Economic Perspectives, 19(3), 19-42.

Svensson, J., 2003. Who must pay bribes, and how much? Evidence from a cross-section of firms. Quarterly Journal of Economics, 118(1), 207-230.

Verrecchia, R., 2001. Essays on Disclosure. Journal of Accounting and Economics 32, 97-180.

Watts, R., J. Zimmerman, 1986. Positive Theory of Accounting. Englewood Cliffs, NJ: Prentice Hall.

Watts, R.L., Zimmerman, J.L., 1978. Towards a positive theory of the determination of accounting standards. Accounting Review, 112-134.

Wei, S.J., 2000. How taxing is corruption on international investors? Review of Economics and Statistics, 82(1), $1-11$.

Williamson, O., 1985. The economic institutions of capitalism: Firms, markets, relational contracting. New York: Free Press.

Xu, L.C., 2011. The effects of business environments on development: A survey of new firm-level evidence. World Bank Research Observer 26 (2), 310-340.

Yazdanfar, D., 2013. Profitability determinants among micro firms: evidence from Swedish data. International Journal of Managerial Finance.

Zheng, B., Xiao, J., 2020. Corruption and Investment: Theory and Evidence from China. Journal of Economic Behavior \& Organization, 175, 40-54. 


\section{Figure 1. McCray Density Plot}

Panels A and B depict the regression discontinuity (RD) density on the left and right sides of the cutoff point, using the local linear regression model and the quadratic polynomial model, respectively. $\mathrm{P}$ indicates that the density estimators are constructed using the $\mathrm{p}^{\text {th }}$ order of the local-polynomial. $\mathrm{H}$ indicates that the density estimators are constructed with the bandwidth (h) on the left and right sides of the cutoff point. Distance equals the number of employees minus the threshold. The null hypothesis of the test assumes that Distance has no density discontinuity around the cutoff point. If firms do not manipulate their number of employees around the auditing threshold, the distribution of Distance should be smooth around the threshold.

Panel A: Local linear regression model

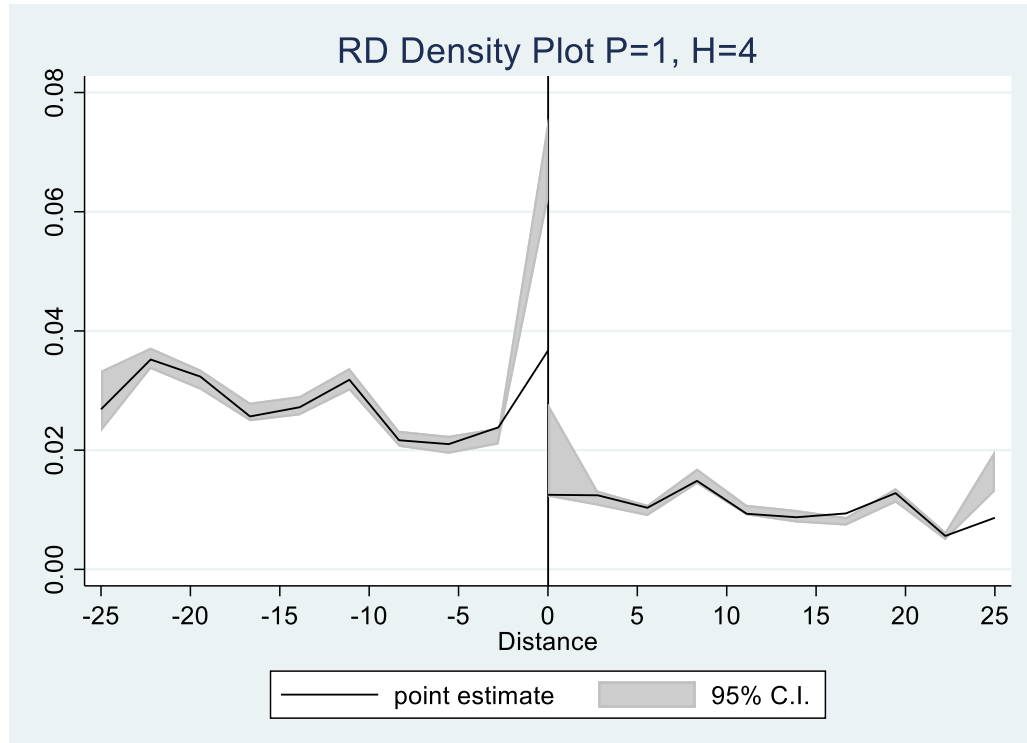

Panel B: Quadratic polynomial model

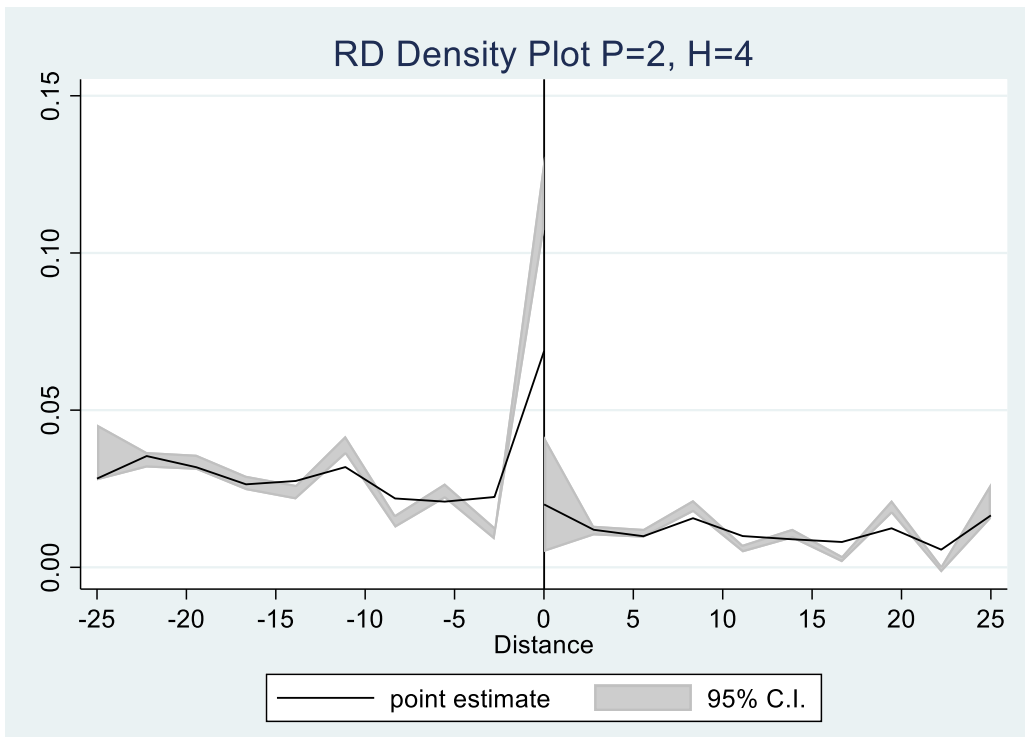




\section{Figure 2. Corruption Obstacles around the Auditing Threshold}

Figures A and B depict the corruption obstacles below and above the mandatory auditing threshold, using the local linear regression model and the quadratic polynomial model, respectively. Distance equals the number of employees minus the auditing threshold.

Panel A: Local linear regression model

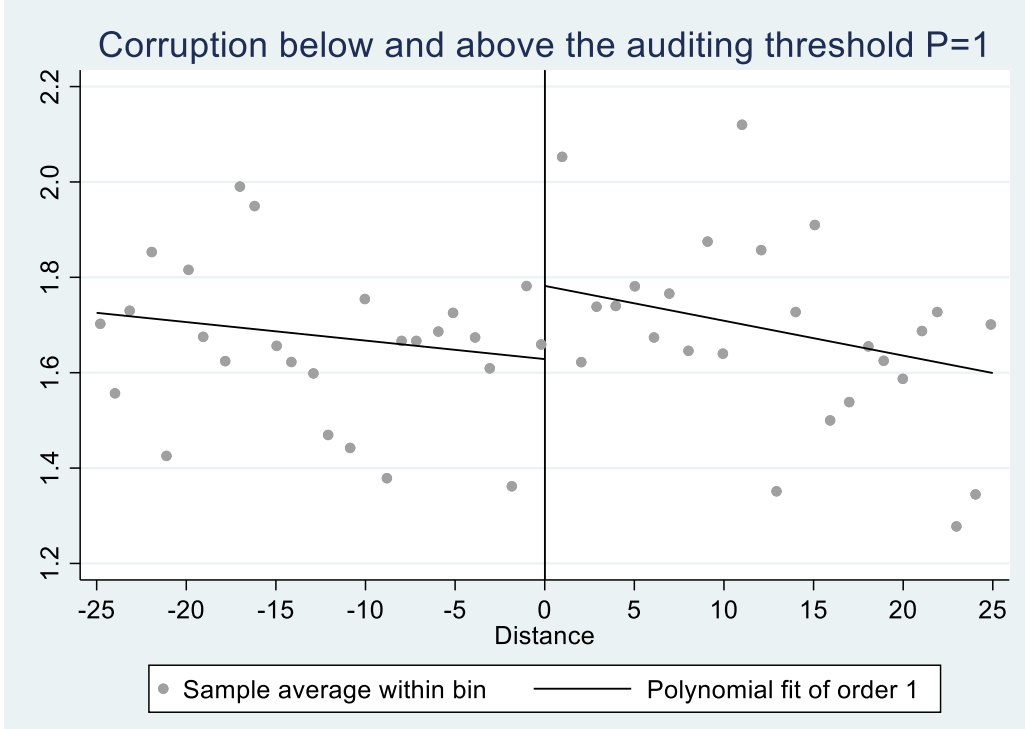

Panel B: Quadratic polynomial model

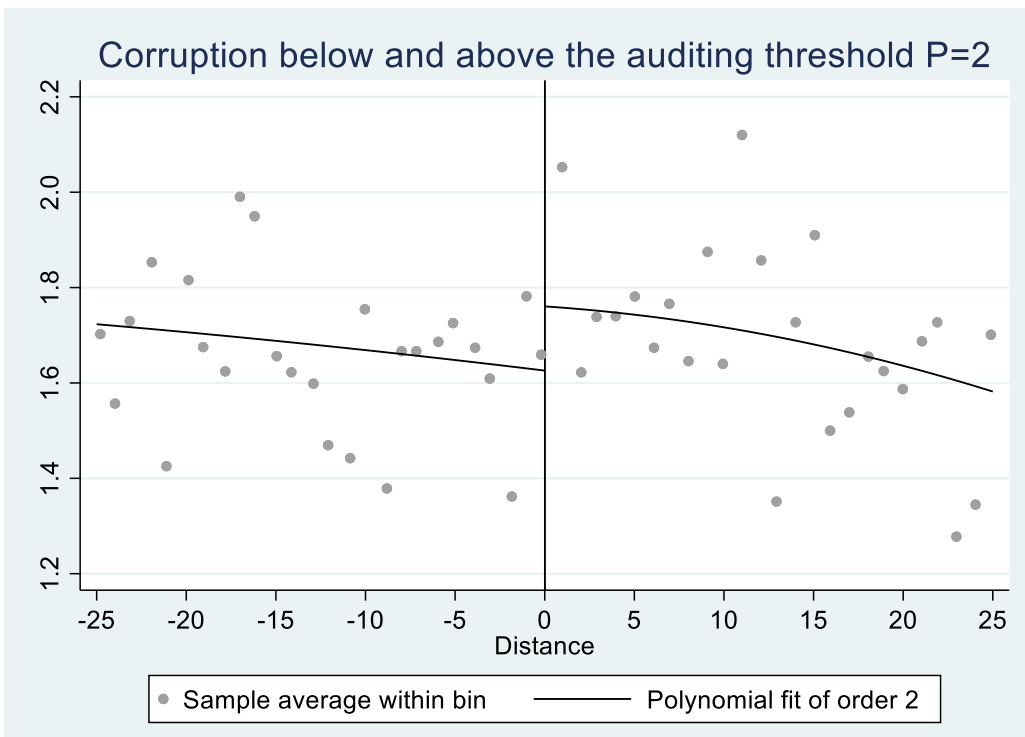




\section{Table 1: Summary Statistics}

This table reports the summary statistics of our sample. Panel A presents the summary statistics of all variables used in our study. Detailed variable definitions and sources are given in Appendix 2. Panel B reports the summary statistics for audited and unaudited firms in the subsamples. The column " $T$-test" reports the two-tail $t$-statistics of two-sample $t$-tests comparing the means of audited and unaudited firms. ${ }^{* * *},{ }^{* *}$, and ${ }^{*}$ indicate statistical significances at the $1 \%, 5 \%$, and $10 \%$ levels, respectively.

\begin{tabular}{lllllll}
\hline \multicolumn{7}{c}{ Panel A: Summary statistics for the full sample } \\
& $N$ & Mean & Median & SD & Min & Max \\
\hline Firm level variables & & & & & & \\
AFS & 148,199 & 0.51 & 1 & 0.50 & 0 & 1 \\
CorruptionObstacle & 145,301 & 1.71 & 2 & 1.49 & 0 & 4 \\
CorruptionDummy & 145,301 & 0.52 & 1 & 0.50 & 0 & 1 \\
LicenseObstacle & 145,553 & 1.06 & 1 & 1.20 & 0 & 4 \\
CustomsObstacle & 136,994 & 1.00 & 0 & 1.22 & 0 & 4 \\
TimeonGovernment & 139,453 & 10.73 & 3 & 19 & 0 & 100 \\
TaxCheckDummy & 149,307 & 0.58 & 1 & 0 & 0 & 1 \\
FirmSize & 150,162 & 97.89 & 20 & 468.67 & 1 & 64,000 \\
FirmAge & 148,909 & 18.35 & 14 & 15.95 & 1 & 340 \\
Experience & 147,009 & 17.50 & 15 & 11.18 & 0 & 75 \\
Government & 148,728 & 0.01 & 0 & 0.07 & 0 & 1 \\
Foreign & 148,675 & 0.08 & 0 & 0.25 & 0 & 1 \\
Compete & 129,918 & 0.50 & 1 & 0.50 & 0 & 1 \\
Exporter & 149,171 & 0.17 & 0 & 0.38 & 0 & 1 \\
CapitalExpenditure & 149,578 & 0.44 & 0 & 0.50 & 0 & 1 \\
Public & 149,842 & 0.05 & 0 & 0.22 & 0 & 1 \\
Company & 149,842 & 0.42 & 0 & 0.49 & 0 & 1 \\
NonCompany & 149,842 & 0.53 & 1 & 0.50 & 0 & 1 \\
\hline
\end{tabular}




\begin{tabular}{lllllll}
\hline \multicolumn{7}{c}{ Panel A-Continued } \\
& $N$ & Mean & Median & SD & Min & Max \\
\hline Country level variables & & & & & & \\
Ln_GDP & 150,953 & 25.27 & 25.23 & 1.99 & 19.48 & 29.53 \\
Ln_GDPperCapita & 150,953 & 8.07 & 8.04 & 1.08 & 5.40 & 10.89 \\
GDPGrowth & 150,953 & 4.44 & 4.79 & 3.70 & -25.91 & 19.68 \\
Inflation & 142,256 & 7.19 & 6.58 & 5.89 & -2.41 & 59.22 \\
PrivateCredit & 146,792 & 38.84 & 31.15 & 40.55 & 1.09 & 972.21 \\
CorruptionControl & 151,219 & -0.48 & -0.52 & 0.62 & -1.59 & 2.29 \\
GovernmentEffectiveness & 151,219 & -0.32 & -0.34 & 0.61 & -1.69 & 1.91 \\
RuleofLaw & 151,219 & -0.45 & -0.47 & 0.61 & -1.83 & 1.97 \\
GovernmentIntegrity & 144,742 & 32.17 & 31 & 11.59 & 10 & 93 \\
FinancialFreedom & 143,670 & 46.77 & 50 & 15.95 & 10 & 80 \\
BusinessFreedom & 144,742 & 59.93 & 61 & 13.06 & 20 & 93 \\
LegalEnglish & 145,197 & 0.30 & 0 & 0.46 & 0 & 1 \\
LegalFrench & 145,197 & 0.47 & 0 & 0.50 & 0 & 1 \\
LegalNordic & 145,197 & 0.00 & 0 & 0.06 & 0 & 1 \\
LegalGerman & 145,197 & 0.09 & 0 & 0.28 & 0 & 1 \\
LegalSocial & 145,197 & 0.13 & 0 & 0.34 & 0 & 1 \\
PowerDistance & 100,482 & 72.97 & 77 & 13.67 & 13 & 104 \\
Individualism & 100,482 & 29.35 & 30 & 15.44 & 2 & 80 \\
UncertaintyAvoidance & 100,482 & 64.80 & 67 & 20.04 & 13 & 101 \\
Masculinity & 100,482 & 49.12 & 46 & 11.98 & 5 & 110 \\
\hline
\end{tabular}




\begin{tabular}{|c|c|c|c|c|c|}
\hline \multicolumn{6}{|c|}{ Panel B: Summary statistics for $A F S$ vs. non- $A F S$ firms } \\
\hline & \multicolumn{2}{|c|}{$A F S$ firms } & \multicolumn{2}{|c|}{ Non- $A F S$ firms } & \multirow{2}{*}{$\begin{array}{l}T \text {-test } \\
\text { Difference (1)-(2) }\end{array}$} \\
\hline & $N$ & Mean (1) & $N$ & Mean (2) & \\
\hline CorruptionObstacle & 72,670 & 1.78 & 69970 & 1.64 & $0.14 * * *$ \\
\hline CorruptionDummy & 72,670 & 0.54 & 69970 & 0.50 & $0.04 * * *$ \\
\hline LicenseObstacle & 72,943 & 1.10 & 69945 & 1.03 & $0.07 * * *$ \\
\hline CustomsObstacle & 69,325 & 1.10 & 65107 & 0.89 & $0.21 * * *$ \\
\hline TimeonGovernment & 69,829 & 11.40 & 67504 & 10.03 & $1.37 * * *$ \\
\hline TaxInspection & 74,265 & 0.66 & 72614 & 0.50 & $0.17 * * *$ \\
\hline FirmSize & 74,605 & 148.28 & 72715 & 46.00 & $102.28^{* * *}$ \\
\hline FirmAge & 74,022 & 20.95 & 72182 & 15.75 & $5.20 * * *$ \\
\hline Experience & 73,113 & 18.42 & 71325 & 16.65 & $1.77 * * *$ \\
\hline Government & 73,792 & 0.01 & 72104 & 0.00 & $0.01 * * *$ \\
\hline Foreign & 73,765 & 0.11 & 72086 & 0.05 & $0.07 * * *$ \\
\hline Compete & 65,595 & 0.49 & 61912 & 0.52 & $-0.03 * * *$ \\
\hline Exporter & 74,208 & 0.23 & 72205 & 0.11 & $0.12 * * *$ \\
\hline CapitalExpenditure & 74,308 & 0.50 & 72728 & 0.38 & $0.13 * * *$ \\
\hline Public & 74,544 & 0.07 & 72350 & 0.03 & $0.04 * * *$ \\
\hline Company & 74,544 & 0.44 & 72350 & 0.40 & $0.04 * * *$ \\
\hline NonCompany & 74,544 & 0.49 & 72350 & 0.57 & $-0.08 * * *$ \\
\hline
\end{tabular}




\section{Table 2: AFS and Firm Corruption Obstacle}

This table reports the impact of AFS on firms' corruption obstacles. The OLS regression results are reported in columns (1) and (3), while Ordered Probit regression results are reported in columns (2) and (4). Macro controls, industry and year fixed effects are included in all regressions. Country fixed effects are included in columns (3) and (4). Standard errors, clustered by country, are reported in parentheses. Detailed variable definitions and sources are given in Appendix 2. ${ }^{* * *},{ }^{* *}$, and ${ }^{*}$ indicate statistical significance at the $1 \%, 5 \%$, and $10 \%$ levels, respectively.

\begin{tabular}{|c|c|c|c|c|}
\hline \multirow[t]{3}{*}{ Dep. Var. } & \multicolumn{4}{|c|}{ Corruption Obstacle } \\
\hline & OLS/LPM & Ordered Probit & OLS/LPM & Ordered Probit \\
\hline & (1) & (2) & (3) & (4) \\
\hline \multirow[t]{2}{*}{$A F S$} & $0.1570 * * *$ & $0.1202 * * *$ & $0.0464 * * *$ & $0.0417 * * *$ \\
\hline & $(0.0483)$ & $(0.0380)$ & $(0.0168)$ & $(0.0144)$ \\
\hline \multirow[t]{2}{*}{ Ln_FirmSize } & $-0.0187 *$ & $-0.0132 *$ & -0.0047 & -0.0029 \\
\hline & $(0.0095)$ & $(0.0077)$ & $(0.0076)$ & $(0.0066)$ \\
\hline \multirow[t]{2}{*}{ Ln_FirmAge } & $0.0330^{*}$ & $0.0263 *$ & 0.0133 & 0.0114 \\
\hline & $(0.0198)$ & $(0.0157)$ & $(0.0110)$ & $(0.0094)$ \\
\hline \multirow[t]{2}{*}{ Experience } & $0.0027 * *$ & $0.0019 *$ & 0.0004 & 0.0002 \\
\hline & $(0.0012)$ & $(0.0010)$ & $(0.0009)$ & $(0.0008)$ \\
\hline \multirow[t]{2}{*}{ Government } & $-0.6244 * * *$ & $-0.5632 * * *$ & $-0.2701 * *$ & $-0.2908 * * *$ \\
\hline & $(0.1460)$ & $(0.1343)$ & $(0.1134)$ & $(0.1047)$ \\
\hline \multirow[t]{2}{*}{ Foreign } & -0.0409 & -0.0333 & -0.01 & -0.0061 \\
\hline & $(0.0385)$ & $(0.0308)$ & $(0.0294)$ & $(0.0251)$ \\
\hline \multirow[t]{2}{*}{ Exporter } & $0.0643 * *$ & $0.0513 * *$ & $0.0507 * * *$ & $0.0438 * * *$ \\
\hline & $(0.0260)$ & $(0.0202)$ & $(0.0180)$ & $(0.0141)$ \\
\hline \multirow[t]{2}{*}{ Compete } & $0.3162 * * *$ & $0.2465 * * *$ & $0.2893 * * *$ & $0.2417 * * *$ \\
\hline & $(0.0427)$ & $(0.0326)$ & $(0.0284)$ & $(0.0238)$ \\
\hline \multirow[t]{2}{*}{ CapitalExpenditure } & $0.0727 * *$ & $0.0597 * *$ & $0.0764 * *$ & $0.0683 * * *$ \\
\hline & $(0.0363)$ & $(0.0273)$ & $(0.0306)$ & $(0.0242)$ \\
\hline \multirow[t]{2}{*}{ Public } & -0.0451 & -0.0353 & $-0.0826 * *$ & $-0.0676 * *$ \\
\hline & $(0.0613)$ & $(0.0498)$ & $(0.0381)$ & $(0.0309)$ \\
\hline \multirow[t]{2}{*}{ Company } & 0.026 & 0.0202 & 0.003 & -0.0024 \\
\hline & $(0.0536)$ & $(0.0445)$ & $(0.0276)$ & $(0.0237)$ \\
\hline Macro Controls & Yes & Yes & Yes & Yes \\
\hline Industry Fixed Effects & Yes & Yes & Yes & Yes \\
\hline Year Fixed Effects & Yes & Yes & Yes & Yes \\
\hline Country Fixed Effects & No & No & Yes & Yes \\
\hline$N$ & 102,016 & 102,016 & 102,016 & 102,016 \\
\hline $\mathrm{R}^{2} /$ Pseudo $\mathrm{R}^{2}$ & 0.13 & 0.05 & 0.22 & 0.08 \\
\hline
\end{tabular}


Table 3: AFS and Firm Corruption Obstacles: IV Analysis

This table reports the IV analysis results. Exclusion restrictions are AFS_CIY (the country-industry-year average probability of AFS) and AFS_Required (1 if a firm's permanent employee number is higher than the auditing threshold, 0 otherwise). To save space, only the coefficients of AFS and the IV are reported in Table 4. All other firm controls, macro controls, and industry and year fixed effects are included in all regressions. Standard errors, clustered by country, are reported in parentheses. Detailed variable definitions and sources are given in Appendix $2 .{ }^{* * *},{ }^{* *}$, and ${ }^{*}$ indicate statistical significance at the $1 \%, 5 \%$, and $10 \%$ levels, respectively.

\begin{tabular}{|c|c|c|c|c|c|c|c|c|}
\hline \multirow{3}{*}{ Dep. Var. } & \multicolumn{4}{|c|}{ 1st Stage } & \multicolumn{4}{|c|}{ 2nd Stage } \\
\hline & \multicolumn{4}{|c|}{ AFS } & \multicolumn{4}{|c|}{ Corruption Obstacle } \\
\hline & (1) & (2) & (3) & (4) & $(5)$ & (6) & $(7)$ & $(8)$ \\
\hline$A F S$ & & & & & $\begin{array}{l}0.5564 * * * \\
(0.1903)\end{array}$ & $\begin{array}{l}0.6211 * * * \\
(0.1967)\end{array}$ & $\begin{array}{l}0.6584 * * * \\
(0.1951)\end{array}$ & $\begin{array}{l}0.1313 \\
(0.0908)\end{array}$ \\
\hline$A F S \_C I Y$ & $\begin{array}{l}0.9076 * * * \\
(0.0137)\end{array}$ & $\begin{array}{l}0.8982 * * * \\
(0.0165)\end{array}$ & $\begin{array}{l}0.8776^{* * *} \\
(0.0203)\end{array}$ & $\begin{array}{l}0.8141 * * * \\
(0.0175)\end{array}$ & & & & \\
\hline $\begin{array}{l}\text { Country-year level } \\
\text { controls }\end{array}$ & $\begin{array}{l}\text { Basic } \\
\text { macro }\end{array}$ & $\begin{array}{l}\text { Basic } \\
\text { macro, } \\
\text { economic } \\
\text { freedom, } \\
\text { and legal } \\
\text { origins }\end{array}$ & $\begin{array}{l}\text { Basic } \\
\text { macro, } \\
\text { economic } \\
\text { freedom, } \\
\text { legal } \\
\text { origins, and } \\
\text { culture } \\
\text { dimensions }\end{array}$ & $\begin{array}{l}\text { Basic } \\
\text { macro }\end{array}$ & $\begin{array}{l}\text { Basic } \\
\text { macro }\end{array}$ & $\begin{array}{l}\text { Basic } \\
\text { macro, } \\
\text { economic } \\
\text { freedom, } \\
\text { and legal } \\
\text { origins }\end{array}$ & $\begin{array}{l}\text { Basic } \\
\text { macro, } \\
\text { economic } \\
\text { freedom, } \\
\text { legal } \\
\text { origins, and } \\
\text { culture } \\
\text { dimensions }\end{array}$ & $\begin{array}{l}\text { Basic } \\
\text { macro }\end{array}$ \\
\hline Firm controls & Yes & Yes & Yes & Yes & Yes & Yes & Yes & Yes \\
\hline Industry Fixed Effects & Yes & Yes & Yes & Yes & Yes & Yes & Yes & Yes \\
\hline Year Fixed Effects & Yes & Yes & Yes & Yes & Yes & Yes & Yes & Yes \\
\hline Country Fixed Effects & No & No & No & Yes & No & No & No & Yes \\
\hline$N$ & 102,016 & 95,630 & 66,645 & 102,016 & 102,016 & 95,630 & 66,645 & 102,016 \\
\hline $\mathrm{R}^{2}$ & & & & & 0.07 & 0.08 & 0.09 & 0.02 \\
\hline $1^{\text {st }}$ Stage F_Test & 4391 & 2953 & 1860 & 2156 & & & & \\
\hline $1^{\text {st }}$ Stage F_Test_P & 0.00 & 0.00 & 0.00 & 0.00 & & & & \\
\hline
\end{tabular}




\section{Table 4: AFS and Firm Corruption Obstacles: Panel Analysis}

This table reports the panel analysis results. Columns (1) and (3) report the whole panel dataset results, while columns (2) and (4) report the subsample results for firms with changed AFS status. Macro controls and firm and year fixed effects are included in all regressions. Industry fixed effects are included in columns (3) and (4). Standard errors, clustered by country, are reported in parentheses. Detailed variable definitions and sources are given in Appendix 2. ${ }^{* * *},{ }^{* *}$, and ${ }^{*}$ indicate statistical significance at the $1 \%, 5 \%$, and $10 \%$ levels, respectively.

\begin{tabular}{|c|c|c|c|c|}
\hline \multirow[t]{3}{*}{ Dep. Var. } & \multicolumn{4}{|c|}{ Corruption Obstacle } \\
\hline & $\begin{array}{l}\text { Whole } \\
\text { Panel }\end{array}$ & $\begin{array}{l}\text { Firms with } \\
\text { changed } \\
\text { AFS }\end{array}$ & $\begin{array}{l}\text { Whole } \\
\text { Panel }\end{array}$ & $\begin{array}{l}\text { Firms with } \\
\text { changed } \\
\text { AFS }\end{array}$ \\
\hline & (1) & (2) & (3) & (4) \\
\hline$A F S$ & $\begin{array}{l}0.0959 * \\
(0.0521)\end{array}$ & $\begin{array}{l}0.1099 * * \\
(0.0516)\end{array}$ & $\begin{array}{l}0.0979 * \\
(0.0561)\end{array}$ & $\begin{array}{l}0.1135 * * \\
(0.0567)\end{array}$ \\
\hline Ln_FirmSize & $\begin{array}{l}-0.007 \\
(0.0329)\end{array}$ & $\begin{array}{l}-0.0552 \\
(0.0492)\end{array}$ & $\begin{array}{l}-0.0083 \\
(0.0344)\end{array}$ & $\begin{array}{l}-0.0704 \\
(0.0479)\end{array}$ \\
\hline Ln_FirmAge & $\begin{array}{l}-0.0065 \\
(0.0443)\end{array}$ & $\begin{array}{l}-0.0094 \\
(0.0728)\end{array}$ & $\begin{array}{l}-0.0075 \\
(0.0472)\end{array}$ & $\begin{array}{l}-0.0035 \\
(0.0777)\end{array}$ \\
\hline Experience & $\begin{array}{l}-0.0011 \\
(0.0020)\end{array}$ & $\begin{array}{l}-0.0024 \\
(0.0036)\end{array}$ & $\begin{array}{l}-0.0015 \\
(0.0020)\end{array}$ & $\begin{array}{l}-0.002 \\
(0.0037)\end{array}$ \\
\hline Government & $\begin{array}{l}-0.6003 \\
(0.3802)\end{array}$ & $\begin{array}{l}-0.723 \\
(0.7034)\end{array}$ & $\begin{array}{l}-0.6464 \\
(0.4265)\end{array}$ & $\begin{array}{l}-0.5969 \\
(0.7201)\end{array}$ \\
\hline Foreign & $\begin{array}{l}0.1761 * * \\
(0.0855)\end{array}$ & $\begin{array}{l}-0.0527 \\
(0.1614)\end{array}$ & $\begin{array}{l}0.1624 * \\
(0.0894)\end{array}$ & $\begin{array}{l}-0.0756 \\
(0.1769)\end{array}$ \\
\hline Exporter & $\begin{array}{l}0.0573 \\
(0.0630)\end{array}$ & $\begin{array}{l}0.0709 \\
(0.1379)\end{array}$ & $\begin{array}{l}0.0865 \\
(0.0644)\end{array}$ & $\begin{array}{l}0.131 \\
(0.1562)\end{array}$ \\
\hline Compete & $\begin{array}{l}0.2825 * * * \\
(0.0518)\end{array}$ & $\begin{array}{l}0.2400 * * \\
(0.0931)\end{array}$ & $\begin{array}{l}0.3003^{* * *} \\
(0.0540)\end{array}$ & $\begin{array}{l}0.2423 * * \\
(0.0950)\end{array}$ \\
\hline CapitalExpenditure & $\begin{array}{l}0.0867 * * \\
(0.0372)\end{array}$ & $\begin{array}{l}0.096 \\
(0.0673)\end{array}$ & $\begin{array}{l}0.0864 * * \\
(0.0395)\end{array}$ & $\begin{array}{l}0.1075 \\
(0.0657)\end{array}$ \\
\hline Public & $\begin{array}{l}-0.0013 \\
(0.1005)\end{array}$ & $\begin{array}{l}-0.1604 \\
(0.1279)\end{array}$ & $\begin{array}{l}-0.0047 \\
(0.1027)\end{array}$ & $\begin{array}{l}-0.1713 \\
(0.1333)\end{array}$ \\
\hline Company & $\begin{array}{l}-0.0135 \\
(0.0733)\end{array}$ & $\begin{array}{l}-0.0447 \\
(0.1124)\end{array}$ & $\begin{array}{l}-0.04 \\
(0.0724)\end{array}$ & $\begin{array}{l}-0.0806 \\
(0.1169)\end{array}$ \\
\hline Macro Controls & Yes & Yes & Yes & Yes \\
\hline Industry Fixed Effects & No & No & Yes & Yes \\
\hline Year Fixed Effects & Yes & Yes & Yes & Yes \\
\hline Firm Fixed Effects & Yes & Yes & Yes & Yes \\
\hline$N$ & 14,678 & 4,382 & 13,598 & 4,030 \\
\hline $\mathrm{R}^{2}$ & 0.63 & 0.61 & 0.63 & 0.61 \\
\hline
\end{tabular}




\section{Table 5: Regression Discontinuity Manipulation Test}

This table reports the regression discontinuity manipulation test results using local polynomial density estimation. The null hypothesis of the test assumes that the running variable has no density discontinuity around the cutoff point. We employ varied parameters $\mathrm{P}$ and $\mathrm{H}$ within the test. $\mathrm{P}$ indicates that the density estimators are constructed using the pth order of the local-polynomial. $\mathrm{H}$ indicates that the density estimators are constructed with the bandwidth (h) on the left and right sides of the cutoff point.

\begin{tabular}{llcl}
\hline $\mathrm{P}$ & Bandwidth & T-stat & $\mathrm{p}$-value \\
\hline $\mathrm{P}=1$ & $\mathrm{H}=+/-2$ & $\cdot$ & $\cdot$ \\
$\mathrm{P}=1$ & $\mathrm{H}=+/-4$ & -9.33 & 0.00 \\
$\mathrm{P}=1$ & $\mathrm{H}=+/-6$ & -7.55 & 0.00 \\
$\mathrm{P}=1$ & $\mathrm{H}=+/-8$ & -7.32 & 0.00 \\
$\mathrm{P}=2$ & $\mathrm{H}=+/-2$ & $\cdot$ & $\cdot$ \\
$\mathrm{P}=2$ & $\mathrm{H}=+/-4$ & -8.76 & 0.00 \\
$\mathrm{P}=2$ & $\mathrm{H}=+/-6$ & -7.44 & 0.00 \\
$\mathrm{P}=2$ & $\mathrm{H}=+/-8$ & -7.14 & 0.00 \\
\hline
\end{tabular}




\section{Table 6: Semi-Structured Surveys}

This table reports the questions used in our interviews and surveys (Panel A) and survey statistics (Panel B).

\section{Panel A: Survey questions}

1. (Q1) Do you feel that your firm was or has been negatively affected by corruption in your country?

(Q1a) If yes, can you describe a specific situation that happened in your firm or another firm with which you are familiar, in the past concerning corruption?

2. (Q2) Do you think disclosing financial information will cause "troubles" to your firm? Please elaborate.

(Q2a) Do you believe that more financial disclosure attracts more "demand for bribes" from bureaucrats? Please elaborate.

3. (Q3) To limit the cost of "getting things done," do you take any specific measures to restrict information disclosure? If yes, what are those measures?

Panel B1: Interviews at SupplySide West Trade Show in Las Vegas, Sept. 28-30, 2017

\begin{tabular}{lccc}
\hline Country/region & $\begin{array}{c}\text { No. of firms } \\
\text { interviewed }\end{array}$ & $\begin{array}{c}\text { No. of firms that did not want to provide detailed } \\
\text { information }\end{array}$ & $\begin{array}{c}\text { No. of useful } \\
\text { surveys }\end{array}$ \\
\hline China & 41 & 40 & 1 \\
India & 5 & 1 & 4 \\
Mexico & 3 & 1 & 2 \\
Argentina & 1 & 0 & 1 \\
Taiwan & 1 & 0 & 1 \\
\hline Total & 51 & 42 & 9 \\
\hline
\end{tabular}

Panel B2: Written Surveys

\begin{tabular}{lccc}
\hline Country & $\begin{array}{c}\text { No. of surveys } \\
\text { returned }\end{array}$ & $\begin{array}{c}\text { No. of firms that did not } \\
\text { want to provide detailed } \\
\text { information }\end{array}$ & No. of useful surveys \\
\hline China & 17 & 8 & 9 \\
\hline
\end{tabular}




\section{Table 7: AFS and Firm Corruption Obstacles: Specific Measures of Corruption}

This table reports the impacts of AFS on firm-specific obstacles by License Obstacle, Customs Obstacle, Time Spent on Government, and Tax Inspection. Macro controls and industry and year fixed effects are included in all regressions. Country fixed effects are included in columns (5) to (8). Standard errors, clustered by country, are reported in parentheses. Detailed variable definitions and sources are given in Appendix $2 .{ }^{* * *},{ }^{* *}$, and *indicate statistical significance at the $1 \%, 5 \%$, and $10 \%$ levels, respectively.

\begin{tabular}{|c|c|c|c|c|c|c|c|c|}
\hline Dep. Var. & $\begin{array}{l}\text { License } \\
\text { Obstacle }\end{array}$ & $\begin{array}{l}\text { Customs } \\
\text { Obstacle }\end{array}$ & $\begin{array}{l}\text { Time } \\
\text { Spend on } \\
\text { Govt. }\end{array}$ & $\begin{array}{l}\text { Tax Check } \\
\text { Dummy }\end{array}$ & $\begin{array}{l}\text { License } \\
\text { Obstacle }\end{array}$ & $\begin{array}{l}\text { Customs } \\
\text { Obstacle }\end{array}$ & $\begin{array}{l}\text { Time } \\
\text { Spend on } \\
\text { Govt. }\end{array}$ & $\begin{array}{l}\text { Tax Check } \\
\text { Dummy }\end{array}$ \\
\hline & $(1)$ & $(2)$ & (3) & (4) & (5) & (6) & $(7)$ & $(8)$ \\
\hline$A F S$ & $\begin{array}{l}0.0683 * \\
(0.0362)\end{array}$ & $\begin{array}{l}0.0851 * * \\
(0.0346)\end{array}$ & $\begin{array}{l}0.9224 * \\
(0.5493)\end{array}$ & $\begin{array}{l}0.1581 * * * \\
(0.0233)\end{array}$ & $\begin{array}{l}0.0369 * \\
(0.0187)\end{array}$ & $\begin{array}{l}0.0832 * * * \\
(0.0243)\end{array}$ & $\begin{array}{l}1.4130 * * * \\
(0.3168)\end{array}$ & $\begin{array}{l}0.1725 * * * \\
(0.0216)\end{array}$ \\
\hline Ln_FirmSize & $\begin{array}{l}0.0094 \\
(0.0073)\end{array}$ & $\begin{array}{l}0.0481^{* * *} \\
(0.0080)\end{array}$ & $\begin{array}{l}0.0915 \\
(0.0984)\end{array}$ & $\begin{array}{l}0.0288 * * * \\
(0.0067)\end{array}$ & $\begin{array}{l}0.0222 * * * \\
(0.0064)\end{array}$ & $\begin{array}{l}0.0579 * * * \\
(0.0066)\end{array}$ & $\begin{array}{l}0.3357 * * * \\
(0.0932)\end{array}$ & $\begin{array}{l}0.0307 * * * \\
(0.0060)\end{array}$ \\
\hline Experience & $\begin{array}{l}-0.0022 * * \\
(0.0010)\end{array}$ & $\begin{array}{l}-0.0021 \\
(0.0013)\end{array}$ & $\begin{array}{l}0.0323 * \\
(0.0169)\end{array}$ & $\begin{array}{l}0.0001 \\
(0.0004)\end{array}$ & $\begin{array}{l}-0.0027 * * * \\
(0.0006)\end{array}$ & $\begin{array}{l}-0.0017 * \\
(0.0009)\end{array}$ & $\begin{array}{l}0.0195 * \\
(0.0117)\end{array}$ & $\begin{array}{l}0 \\
(0.0002)\end{array}$ \\
\hline Government & $\begin{array}{l}-0.3497 * * * \\
(0.1000)\end{array}$ & $\begin{array}{l}-0.3484 * * * \\
(0.1100)\end{array}$ & $\begin{array}{l}0.8155 \\
(1.6602)\end{array}$ & $\begin{array}{l}-0.1260 * \\
(0.0706)\end{array}$ & $\begin{array}{l}-0.1838 * * \\
(0.0731)\end{array}$ & $\begin{array}{l}-0.2012 * * \\
(0.0897)\end{array}$ & $\begin{array}{l}1.2455 \\
(1.1016)\end{array}$ & $\begin{array}{l}-0.127 \\
(0.0878)\end{array}$ \\
\hline Compete & $\begin{array}{l}0.2210^{* * *} \\
(0.0258)\end{array}$ & $\begin{array}{l}0.1787 * * * \\
(0.0318)\end{array}$ & $\begin{array}{l}0.0996 \\
(0.3548)\end{array}$ & $\begin{array}{l}0.0162 \\
(0.0102)\end{array}$ & $\begin{array}{l}0.1824 * * * \\
(0.0164)\end{array}$ & $\begin{array}{l}0.1484 * * * \\
(0.0276)\end{array}$ & $\begin{array}{l}0.064 \\
(0.2555)\end{array}$ & $\begin{array}{l}0.0186 * \\
(0.0094)\end{array}$ \\
\hline CapitalExpenditure & $\begin{array}{l}0.0989 * * * \\
(0.0262)\end{array}$ & $\begin{array}{l}0.1124 * * * \\
(0.0272)\end{array}$ & $\begin{array}{l}1.7525 * * * \\
(0.3581)\end{array}$ & $\begin{array}{l}0.0701 * * * \\
(0.0171)\end{array}$ & $\begin{array}{l}0.0933 * * * \\
(0.0162)\end{array}$ & $\begin{array}{l}0.1163 * * * \\
(0.0201)\end{array}$ & $\begin{array}{l}1.4159 * * * \\
(0.2499)\end{array}$ & $\begin{array}{l}0.0691 * * * \\
(0.0155)\end{array}$ \\
\hline Public & $\begin{array}{l}-0.0068 \\
(0.0350)\end{array}$ & $\begin{array}{l}-0.0820^{*} \\
(0.0471)\end{array}$ & $\begin{array}{l}3.4779 \text { *** } \\
(0.9105)\end{array}$ & $\begin{array}{l}0.0174 \\
(0.0207)\end{array}$ & $\begin{array}{l}-0.0126 \\
(0.0241)\end{array}$ & $\begin{array}{l}-0.0306 \\
(0.0313)\end{array}$ & $\begin{array}{l}1.0896^{* *} \\
(0.5145)\end{array}$ & $\begin{array}{l}0.0074 \\
(0.0139)\end{array}$ \\
\hline
\end{tabular}




\begin{tabular}{lllllllll} 
Company & -0.0044 & 0.0063 & $3.3824 * * *$ & 0.0045 & -0.0004 & $0.0776 * * *$ & $0.8431^{*}$ & -0.0065 \\
& $(0.0336)$ & $(0.0372)$ & $(0.6837)$ & $(0.0172)$ & $(0.0169)$ & $(0.0180)$ & $(0.4722)$ & $(0.0082)$ \\
Macro Controls & Yes & Yes & Yes & Yes & Yes & Yes & Yes & Yes \\
Industry Fixed Effects & Yes & Yes & Yes & Yes & Yes & Yes & Yes & Yes \\
Year Fixed Effects & Yes & Yes & Yes & Yes & Yes & Yes & Yes & Yes \\
Country Fixed Effects & No & No & No & No & Yes & Yes & Yes & Yes \\
$N$ & 102,374 & 96,359 & 98,843 & 105,136 & 102,374 & 96,359 & 98,843 & 105,136 \\
$\mathrm{R}^{2}$ & 0.07 & 0.09 & 0.06 & 0.11 & 0.14 & 0.16 & 0.13 & 0.19 \\
\hline
\end{tabular}




\section{Table 8: AFS and Firm Corruption Obstacle: Institutional Developments}

This table reports the impacts of institutional developments on the AFS-corruption relationship. We add three interactions, $A F S^{*}$ CorruptionControl, $A F S^{*}$ GovernmentEffectiveness, and $A F S^{*}$ RuleofLaw to Equation (2). Macro controls and industry and year fixed effects are included in all regressions. Country fixed effects are included in columns (4) to (6). Standard errors, clustered by country, are reported in parentheses. Detailed variable definitions and sources are given in Appendix $2 .^{* * *},{ }^{* *}$, and ${ }^{*}$ indicate statistical significance at the $1 \%, 5 \%$, and $10 \%$ levels, respectively.

\begin{tabular}{|c|c|c|c|c|c|c|}
\hline \multirow[t]{2}{*}{ Dep. Var. } & \multicolumn{6}{|c|}{ Corruption Obstacle } \\
\hline & $(1)$ & (2) & (3) & $(4)$ & $(5)$ & (6) \\
\hline$A F S$ & $\begin{array}{l}0.0968 * \\
(0.0540)\end{array}$ & $\begin{array}{l}0.1264 * * \\
(0.0489)\end{array}$ & $\begin{array}{l}0.1029 * \\
(0.0547)\end{array}$ & $\begin{array}{l}0.0127 \\
(0.0200)\end{array}$ & $\begin{array}{l}0.0289 \\
(0.0184)\end{array}$ & $\begin{array}{l}0.017 \\
(0.0191)\end{array}$ \\
\hline AFS ${ }^{*}$ CorruptionControl & $\begin{array}{l}-0.1139 * * \\
(0.0556)\end{array}$ & & & $\begin{array}{l}-0.0764 * * * \\
(0.0252)\end{array}$ & & \\
\hline CorruptionControl & $\begin{array}{l}-0.4612 * * * \\
(0.0802)\end{array}$ & & & $\begin{array}{l}-0.5538 * * \\
(0.2451)\end{array}$ & & \\
\hline AFS*GovernmentEffectiveness & & $\begin{array}{l}-0.1394 * * \\
(0.0637)\end{array}$ & & & $\begin{array}{l}-0.0636 * * \\
(0.0264)\end{array}$ & \\
\hline GovernmentEffectiveness & & $\begin{array}{l}-0.6132 * * * \\
(0.1301)\end{array}$ & & & $\begin{array}{l}-0.4107 \\
(0.3160)\end{array}$ & \\
\hline AFS*RuleofLaw & & & $\begin{array}{l}-0.1254 * * \\
(0.0580)\end{array}$ & & & $\begin{array}{l}-0.0750 * * * \\
(0.0252)\end{array}$ \\
\hline RuleofLaw & & & $\begin{array}{l}-0.3834 * * * \\
(0.0965)\end{array}$ & & & $\begin{array}{l}-0.6217^{* *} \\
(0.2935)\end{array}$ \\
\hline Firm \& Macro Controls & Yes & Yes & Yes & Yes & Yes & Yes \\
\hline Industry \& Year Fixed Effects & Yes & Yes & Yes & Yes & Yes & Yes \\
\hline Country Fixed Effects & No & No & No & Yes & Yes & Yes \\
\hline$N$ & 102,016 & 102,016 & 102,016 & 102,016 & 102,016 & 102,016 \\
\hline $\mathrm{R}^{2}$ & 0.12 & 0.13 & 0.11 & 0.22 & 0.22 & 0.22 \\
\hline
\end{tabular}




\section{Appendix 1: Number and Percent of Audited Firms by Country}

\begin{tabular}{|c|c|c|c|c|c|c|c|}
\hline \multirow[t]{2}{*}{ Country } & \multirow[t]{2}{*}{$N$} & \multicolumn{2}{|c|}{ Audited } & \multirow[t]{2}{*}{ Country } & \multirow[t]{2}{*}{$N$} & \multicolumn{2}{|c|}{ Audited } \\
\hline & & $N 1$ & $\%$ & & & $N 1$ & $\%$ \\
\hline Albania* & 977 & 256 & $26 \%$ & Chile* & 2,029 & 1040 & $51 \%$ \\
\hline Angola* & 754 & 102 & $14 \%$ & China* & 2,658 & 1886 & $71 \%$ \\
\hline Antigua and Barbuda* & 150 & 79 & $53 \%$ & Colombia* & 2,929 & 1715 & $59 \%$ \\
\hline Argentina* & 3,077 & 1994 & $65 \%$ & Congo* & 135 & 84 & $62 \%$ \\
\hline Armenia* & 728 & 160 & $22 \%$ & Costa Rica* & 528 & 318 & $60 \%$ \\
\hline Azerbaijan* & 756 & 344 & $46 \%$ & Croatia* & 1,373 & 622 & $45 \%$ \\
\hline Bahamas* & 146 & 88 & $60 \%$ & Cyprus* & 240 & 168 & $70 \%$ \\
\hline Bangladesh* & 2,941 & 1255 & $43 \%$ & Czech Republic* & 495 & 255 & $52 \%$ \\
\hline Barbados* & 149 & 124 & $83 \%$ & Djibouti & 259 & 118 & $46 \%$ \\
\hline Belarus* & 1,224 & 471 & $38 \%$ & Dominica* & 150 & 72 & $48 \%$ \\
\hline Belize* & 150 & 103 & $69 \%$ & Dominican Republic* & 701 & 522 & $74 \%$ \\
\hline Benin* & 297 & 182 & $61 \%$ & $\mathrm{DRC}^{*}$ & 1,208 & 295 & $24 \%$ \\
\hline Bhutan* & 503 & 249 & $50 \%$ & Ecuador* & 1,380 & 755 & $55 \%$ \\
\hline Bolivia* & 1,331 & 1034 & $78 \%$ & Egypt* & 4,677 & 3761 & $80 \%$ \\
\hline Bosnia and Herzegovina* & 1,052 & 647 & $62 \%$ & El Salvador* & 1,757 & 1532 & $87 \%$ \\
\hline Botswana* & 606 & 425 & $70 \%$ & Eritrea & 172 & 143 & $83 \%$ \\
\hline Brazil* & 1,778 & 402 & $23 \%$ & Estonia* & 536 & 312 & $58 \%$ \\
\hline Bulgaria* & 1,578 & 655 & $42 \%$ & Eswatini* & 454 & 340 & $75 \%$ \\
\hline Burkina Faso* & 384 & 195 & $51 \%$ & Ethiopia & 1,485 & 1014 & $68 \%$ \\
\hline Burundi & 427 & 115 & $27 \%$ & Fiji* & 159 & 143 & $90 \%$ \\
\hline Cambodia* & 796 & 199 & $25 \%$ & Gabon* & 167 & 72 & $43 \%$ \\
\hline Cameroon* & 703 & 452 & $64 \%$ & Gambia* & 325 & 108 & $33 \%$ \\
\hline Cape Verde & 151 & 55 & $36 \%$ & Georgia* & 711 & 263 & $37 \%$ \\
\hline
\end{tabular}


Appendix 1- Continued

\begin{tabular}{|c|c|c|c|c|c|c|c|}
\hline \multirow[t]{2}{*}{ Country } & \multirow[t]{2}{*}{$N$} & \multicolumn{2}{|c|}{ Audited } & \multirow[t]{2}{*}{ Country } & \multirow[t]{2}{*}{$N$} & \multicolumn{2}{|c|}{ Audited } \\
\hline & & $N 1$ & $\%$ & & & $N 1$ & $\%$ \\
\hline Greece* & 599 & 287 & $48 \%$ & Lithuania* & 526 & 183 & $35 \%$ \\
\hline Grenada* & 152 & 92 & $61 \%$ & Madagascar* & 947 & 453 & $48 \%$ \\
\hline Guatemala* & 1,442 & 958 & $66 \%$ & Malawi* & 659 & 374 & $57 \%$ \\
\hline Guinea* & 365 & 71 & $19 \%$ & Malaysia* & 966 & 449 & $46 \%$ \\
\hline Guinea Bissau* & 158 & 13 & $8 \%$ & Mali* & 1,004 & 404 & $40 \%$ \\
\hline Guyana* & 164 & 150 & $91 \%$ & Malta* & 242 & 220 & $91 \%$ \\
\hline Honduras* & 1,102 & 705 & $64 \%$ & Mauritania & 386 & 113 & $29 \%$ \\
\hline Hungary* & 585 & 361 & $62 \%$ & Mauritius* & 392 & 247 & $63 \%$ \\
\hline India* & 9,146 & 7610 & $83 \%$ & Mexico* & 2,895 & 1327 & $46 \%$ \\
\hline Indonesia* & 2,730 & 555 & $20 \%$ & Micronesia & 67 & 17 & $25 \%$ \\
\hline Iraq* & 744 & 316 & $42 \%$ & Moldova* & 1,054 & 265 & $25 \%$ \\
\hline Israel* & 479 & 448 & $94 \%$ & Mongolia* & 1,071 & 886 & $83 \%$ \\
\hline Italy* & 750 & 159 & $21 \%$ & Montenegro* & 385 & 172 & $45 \%$ \\
\hline Ivory Coast* & 868 & 300 & $35 \%$ & Morocco & 392 & 205 & $52 \%$ \\
\hline Jamaica* & 354 & 270 & $76 \%$ & Mozambique & 1,080 & 460 & $43 \%$ \\
\hline Jordan* & 1,146 & 609 & $53 \%$ & Myanmar* & 1,164 & 266 & $23 \%$ \\
\hline Kazakhstan* & 2,526 & 590 & $23 \%$ & Namibia* & 880 & 670 & $76 \%$ \\
\hline Kenya* & 2,424 & 1909 & $79 \%$ & $\mathrm{Nepal}^{*}$ & 849 & 679 & $80 \%$ \\
\hline Kosovo* & 457 & 100 & $22 \%$ & Nicaragua* & 1,133 & 566 & $50 \%$ \\
\hline Kyrgyz Republic & 847 & 323 & $38 \%$ & Niger* & 298 & 149 & $50 \%$ \\
\hline Lao PDR & 1,317 & 309 & $23 \%$ & Nigeria* & 4,461 & 923 & $21 \%$ \\
\hline Latvia* & 591 & 332 & $56 \%$ & North Macedonia & 723 & 321 & $44 \%$ \\
\hline Lebanon & 555 & 499 & $90 \%$ & Pakistan* & 2,043 & 698 & $34 \%$ \\
\hline Lesotho* & 295 & 204 & $69 \%$ & Panama* & 950 & 691 & $73 \%$ \\
\hline Liberia* & 295 & 89 & $30 \%$ & Papua New Guinea* & 65 & 44 & $68 \%$ \\
\hline
\end{tabular}


Appendix 1- Continued

\begin{tabular}{|c|c|c|c|c|c|c|c|}
\hline \multirow[t]{2}{*}{ Country } & \multirow[t]{2}{*}{$N$} & \multicolumn{2}{|c|}{ Audited } & \multirow[t]{2}{*}{ Country } & \multirow[t]{2}{*}{$N$} & \multicolumn{2}{|c|}{ Audited } \\
\hline & & $N 1$ & $\%$ & & & $N 1$ & $\%$ \\
\hline Paraguay* & 1,322 & 526 & $40 \%$ & Sweden* & 596 & 573 & $96 \%$ \\
\hline Peru* & 2,616 & 901 & $34 \%$ & Tajikistan & 1,047 & 300 & $29 \%$ \\
\hline Philippines* & 2,579 & 2268 & $88 \%$ & Tanzania* & 1,191 & 537 & $45 \%$ \\
\hline Poland* & 953 & 241 & $25 \%$ & Thailand* & 825 & 210 & $25 \%$ \\
\hline Romania* & 1,035 & 399 & $39 \%$ & Timor-Leste* & 275 & 83 & $30 \%$ \\
\hline Russia* & 6,400 & 1638 & $26 \%$ & Togo $*$ & 304 & 177 & $58 \%$ \\
\hline Rwanda* & 450 & 218 & $48 \%$ & Tonga & 148 & 76 & $51 \%$ \\
\hline Samoa & 107 & 77 & $72 \%$ & Trinidad and Tobago* & 366 & 300 & $82 \%$ \\
\hline Senegal* & 1,100 & 288 & $26 \%$ & Tunisia & 592 & 464 & $78 \%$ \\
\hline Serbia* & 1,090 & 623 & $57 \%$ & Turkey* & 4,031 & 1908 & $47 \%$ \\
\hline Sierra Leone* & 302 & 85 & $28 \%$ & Uganda* & 1,282 & 604 & $47 \%$ \\
\hline Slovak Republic* & 537 & 282 & $53 \%$ & Ukraine* & 1,790 & 528 & $29 \%$ \\
\hline Slovenia* & 544 & 209 & $38 \%$ & Uruguay* & 1,556 & 616 & $40 \%$ \\
\hline Solomon Islands & 150 & 129 & $86 \%$ & Uzbekistan* & 1,972 & 528 & $27 \%$ \\
\hline South Africa* & 937 & 704 & $75 \%$ & Vanuatu & 128 & 57 & $45 \%$ \\
\hline South Sudan & 724 & 208 & $29 \%$ & Venezuela* & 789 & 603 & $76 \%$ \\
\hline Sri Lanka* & 588 & 384 & $65 \%$ & Vietnam* & 2,032 & 693 & $34 \%$ \\
\hline St. Kitts and Nevis* & 148 & 102 & $69 \%$ & West Bank and Gaza & 784 & 623 & $79 \%$ \\
\hline St. Lucia* & 150 & 71 & $47 \%$ & Yemen* & 824 & 276 & $33 \%$ \\
\hline St. Vincent and Grenadines* & 150 & 118 & $79 \%$ & Zambia* & 1,190 & 739 & $62 \%$ \\
\hline Sudan & 610 & 344 & $56 \%$ & Zimbabwe* & 1,196 & 723 & $60 \%$ \\
\hline Suriname* & 384 & 237 & $62 \%$ & Total & 148,199 & 74951 & $51 \%$ \\
\hline
\end{tabular}




\section{Appendix 2: Variables, Definitions, and Data Sources}

Data Sources: WBES $=$ World Bank Enterprise Survey $($ WBES); WDI $=$ World Development Indicators, World Bank; WGI = Worldwide Governance Indicators, World Bank; IFS = International Financial Statistics.

\begin{tabular}{|c|c|c|}
\hline Variable & Definition & Data Source \\
\hline \multirow[b]{2}{*}{$A F S$} & Key explanatory variable: & \multirow{3}{*}{ WBES k21 } \\
\hline & $\begin{array}{l}\text { Dummy variable that equals } 1 \text { if a firm's annual financial } \\
\text { statements were checked and certified by an external } \\
\text { auditor, } 0 \text { otherwise. }\end{array}$ & \\
\hline \multirow[b]{2}{*}{ CorruptionObstacle } & Dependent variables: & \\
\hline & $\begin{array}{l}\text { "How problematic is corruption for the current operations } \\
\text { of a business?" No Obstacle }=0 \text {, Minor Obstacle }=1 \text {, } \\
\text { Moderate Obstacle }=2 \text {, Major Obstacle }=3 \text {, and Very } \\
\text { Severe Obstacle }=4 \text {. }\end{array}$ & WBES j30f \\
\hline CorruptionDummy & $\begin{array}{l}\text { Dummy variable that equals } 1 \text { if corruption obstacles } \\
\text { equal to } 2 \text { (moderate), } 3 \text { (major), or } 4 \text { (very severe), and } 0 \\
\text { otherwise. }\end{array}$ & WBES j30f \\
\hline LicenseObstacle & $\begin{array}{l}\text { "How problematic are business licensing and permits for } \\
\text { the current operations of a business?" No Obstacle }=0 \text {, } \\
\text { Minor Obstacle }=1 \text {, Moderate Obstacle }=2 \text {, Major } \\
\text { Obstacle }=3 \text {, and Very Severe Obstacle }=4 \text {. }\end{array}$ & WBES j30c \\
\hline CustomsObstacle & $\begin{array}{l}\text { "How problematic are customs and trade regulations for } \\
\text { the current operations of a business?" No Obstacle }=0 \text {, } \\
\text { Minor Obstacle }=1 \text {, Moderate Obstacle }=2 \text {, Major } \\
\text { Obstacle }=3 \text {, and Very Severe Obstacle }=4 \text {. }\end{array}$ & WBES d30b \\
\hline TimeonGovernment & $\begin{array}{l}\text { "What } \% \text { of senior management time was spent in dealing } \\
\text { with govt regulations?" }\end{array}$ & WBES j2 \\
\hline TaxCheckDummy & $\begin{array}{l}\text { "Over the last } 12 \text { months, was this establishment } \\
\text { inspected by tax officials?" }\end{array}$ & WBES j3 \\
\hline
\end{tabular}




\begin{tabular}{|c|c|c|}
\hline Variable & Definition & Data Source \\
\hline & Firm characteristics: & \\
\hline FirmSize & $\begin{array}{l}\text { The natural log of a firm's permanent, full-time } \\
\text { employees at end year (t-1) }\end{array}$ & WBES 11 \\
\hline FirmAge & $\begin{array}{l}\text { The natural log of a firm's actual age, age=survey year - } \\
\text { firm founding year }\end{array}$ & WBES b5 \\
\hline Experience & $\begin{array}{l}\text { "How many years of experience working in this sector } \\
\text { does the top manager have?" }\end{array}$ & WBES b7 \\
\hline Government & $\begin{array}{l}\text { Dummy variable that equals } 1 \text { if firm is owned by } \\
\text { government/ state, } 0 \text { otherwise. }\end{array}$ & WBES b2c \\
\hline Foreign & $\begin{array}{l}\text { Dummy variable that equals } 1 \text { if any foreign company or } \\
\text { individual has a financial stake in the ownership of the } \\
\text { firm, } 0 \text { otherwise. }\end{array}$ & WBES b2b \\
\hline Compete & $\begin{array}{l}\text { Dummy variable that equals } 1 \text { if the firm answered 'Yes' } \\
\text { to the question: "Does this establishment compete against } \\
\text { unregistered or informal firms?" }\end{array}$ & WBES e11 \\
\hline Exporter & $\begin{array}{l}\text { Dummy variable that equals } 1 \text { if the firm is an exporter, } 0 \\
\text { otherwise. }\end{array}$ & WBES d3c \\
\hline CapitalExpenditure & $\begin{array}{l}\text { Dummy variable that equals } 1 \text { if firm purchased fixed } \\
\text { assets, such as machinery, vehicles, equipment, land or } \\
\text { buildings at year (t-1), and } 0 \text { otherwise. }\end{array}$ & WBES k4 \\
\hline Public & $\begin{array}{l}\text { Legal status of the firm is shareholding company with } \\
\text { traded shares }\end{array}$ & WBES b1 \\
\hline Company & $\begin{array}{l}\text { Legal status of the firm is shareholding company with } \\
\text { non-traded shares }\end{array}$ & WBES b1 \\
\hline NonCompany & $\begin{array}{l}\text { Legal status of the firm includes sole proprietorship, } \\
\text { partnership, limited partnership and other }\end{array}$ & WBES b1 \\
\hline
\end{tabular}




\section{Appendix 2- Continued}

\begin{tabular}{|c|c|c|}
\hline Variable & Definition & Data Source \\
\hline & Country-level variables: & \\
\hline$L n \_G D P$ & The natural log of GDP in constant 2000 US\$ & WDI \\
\hline Ln_GDP per capita & The natural log of GDP per capita in constant 2000 US\$ & WDI \\
\hline GDPGrowth & GDP growth rate & WDI \\
\hline Inflation & The natural log difference of consumer prices & WDI \\
\hline PrivateCredit & Private credit by deposit money banks to GDP. & IFS \\
\hline CorruptionControl & $\begin{array}{l}\text { Country-level corruption estimate and ranges from }-2.5 \\
\text { (weak) to } 2.5 \text { (strong) governance performance }\end{array}$ & WGI \\
\hline GovernmentEffectiveness & $\begin{array}{l}\text { Country-level estimate for the quality of public services. } \\
\text { It ranges from }-2.5 \text { (weak) to } 2.5 \text { (strong) governance } \\
\text { performance }\end{array}$ & WGI \\
\hline RuleofLaw & $\begin{array}{l}\text { Country-level estimate for rule of society, contract } \\
\text { enforcement, property rights, et al. It ranges from }-2.5 \\
\text { (weak) to } 2.5 \text { (strong) governance performance }\end{array}$ & WGI \\
\hline GovernmentIntegrity & $\begin{array}{l}\text { A measure of government integrity. The score ranges } \\
\text { from } 0 \text { to } 100 \text {, with } 100 \text { being the best. }\end{array}$ & $\begin{array}{l}\text { The Heritage } \\
\text { Foundation }\end{array}$ \\
\hline FinancialFreedom & $\begin{array}{l}\text { An estimate of banking efficiency. The score ranges from } \\
0 \text { to } 100 \text {, with } 100 \text { being the freest. }\end{array}$ & $\begin{array}{l}\text { The Heritage } \\
\text { Foundation }\end{array}$ \\
\hline BusinessFreedom & $\begin{array}{l}\text { An estimate of the business freedom. The score ranges } \\
\text { from } 0 \text { to } 100 \text {, with } 100 \text { being the freest. }\end{array}$ & $\begin{array}{l}\text { The Heritage } \\
\text { Foundation }\end{array}$ \\
\hline LegalEnglish & $\begin{array}{l}\text { Dummy variable that equals } 1 \text { if the country's legal origin } \\
\text { is English, } 0 \text { otherwise. }\end{array}$ & $\begin{array}{l}\text { La Porta et al. } \\
\text { (1999) }\end{array}$ \\
\hline LegalFrench & $\begin{array}{l}\text { Dummy variable that equals } 1 \text { if the country's legal origin } \\
\text { is French, } 0 \text { otherwise. }\end{array}$ & $\begin{array}{l}\text { La Porta et al. } \\
\text { (1999) }\end{array}$ \\
\hline LegalNordic & $\begin{array}{l}\text { Dummy variable that equals } 1 \text { if the country's legal origin } \\
\text { is Nordic, } 0 \text { otherwise. }\end{array}$ & $\begin{array}{l}\text { La Porta et al. } \\
\text { (1999) }\end{array}$ \\
\hline LegalGerman & $\begin{array}{l}\text { Dummy variable that equals } 1 \text { if the country's legal origin } \\
\text { is German, } 0 \text { otherwise. }\end{array}$ & $\begin{array}{l}\text { La Porta et al. } \\
\text { (1999) }\end{array}$ \\
\hline LegalSocial & $\begin{array}{l}\text { Dummy variable that equals } 1 \text { if the country's legal origin } \\
\text { is Socialist, } 0 \text { otherwise. }\end{array}$ & $\begin{array}{l}\text { La Porta et al. } \\
\text { (1999) }\end{array}$ \\
\hline Power Distance & $\begin{array}{l}\text { A measure of a country's acceptance of unequal power } \\
\text { distribution. }\end{array}$ & $\begin{array}{l}\text { Hofstede } \\
\text { Insights }\end{array}$ \\
\hline Individualism & $\begin{array}{l}\text { A measure of a country's people who feel independent as } \\
\text { a member of the society. }\end{array}$ & $\begin{array}{l}\text { Hofstede } \\
\text { Insights }\end{array}$ \\
\hline UncertaintyAvoidance & A measure of a country's tolerance of uncertainty. & $\begin{array}{l}\text { Hofstede } \\
\text { Insights }\end{array}$ \\
\hline Masculinity & A measure of a country's endorsement of the use of force. & $\begin{array}{l}\text { Hofstede } \\
\text { Insights }\end{array}$ \\
\hline
\end{tabular}




\begin{tabular}{|c|c|c|c|c|c|}
\hline Dep. Var. CO & Coef. & Std & z-score & p-value & Bandwidth \\
\hline \multirow{4}{*}{$\begin{array}{c}\text { Conventional RD } \\
\text { estimates with } \\
\text { conventional variance } \\
\text { estimator }\end{array}$} & 0.535 & 0.310 & 1.73 & 0.08 & $+/-2$ \\
\hline & 1.314 & 0.806 & 1.63 & 0.10 & $+/-4$ \\
\hline & 0.684 & 0.460 & 1.49 & 0.14 & $+/-6$ \\
\hline & 0.403 & 0.341 & 1.18 & 0.24 & $+/-8$ \\
\hline \multirow{4}{*}{$\begin{array}{c}\text { Bias-corrected RD } \\
\text { estimates with } \\
\text { conventional variance } \\
\text { estimator }\end{array}$} & 0.454 & 0.310 & 1.47 & 0.14 & $+/-2$ \\
\hline & 2.015 & 0.806 & 2.50 & 0.01 & $+/-4$ \\
\hline & 1.480 & 0.460 & 3.21 & 0.00 & $+/-6$ \\
\hline & 0.952 & 0.341 & 2.79 & 0.01 & $+/-8$ \\
\hline \multirow{4}{*}{$\begin{array}{l}\text { Bias-corrected RD } \\
\text { estimates with robust } \\
\text { variance estimator }\end{array}$} & 0.454 & 0.265 & 1.71 & 0.09 & $+/-2$ \\
\hline & 2.015 & 1.487 & 1.36 & 0.18 & $+/-4$ \\
\hline & 1.480 & 0.960 & 1.54 & 0.12 & $+/-6$ \\
\hline & 0.952 & 0.619 & 1.54 & 0.12 & $+/-8$ \\
\hline
\end{tabular}

Panel B: Testing corruption obstacles around the threshold with control variables

\begin{tabular}{lllllc}
\hline Dep. Var. CO & Coef. & Std & z-score & p-value & Bandwidth \\
\hline & & & & & \\
Conventional RD & 0.430 & 0.314 & 1.37 & 0.17 & $+/-2$ \\
$\quad \begin{array}{l}\text { estimates with } \\
\text { conventional variance }\end{array}$ & 1.154 & 0.782 & 1.48 & 0.14 & $+/-4$ \\
$\quad$ estimator & 0.133 & 0.451 & 0.73 & 0.47 & $+/-6$ \\
& & 0.326 & 0.41 & 0.68 & $+/-8$ \\
$\quad 0.359$ & 0.314 & 1.15 & 0.25 & $+/-2$ \\
Bias-corrected RD & 1.826 & 0.782 & 2.34 & 0.02 & $+/-4$ \\
$\quad$ estimates with & 1.472 & 0.451 & 3.27 & 0.00 & $+/-6$ \\
conventional variance & 0.465 & 0.326 & 1.43 & 0.15 & $+/-8$ \\
$\quad$ estimator & & & & & \\
& 0.359 & 0.269 & 1.34 & 0.18 & $+/-2$ \\
& 1.826 & 1.450 & 1.26 & 0.21 & $+/-4$ \\
Bias-corrected RD & 1.472 & 0.926 & 1.59 & 0.11 & $+/-6$ \\
estimates with robust & 0.465 & 0.593 & 0.78 & 0.43 & $+/-8$ \\
variance estimator & & & & & \\
\hline
\end{tabular}




\title{
Internet Appendix for
}

\section{"The Dark Side of Transparency in Developing Countries:}

\section{The Link between Financial Reporting Practices and Corruption"}

\begin{abstract}
This online appendix provides robustness tests and employee threshold information for the RDD analysis described in "The Dark Side of Transparency in Developing Countries: The Link between Financial Reporting Practices and Corruption."
\end{abstract}




\section{Table IA1. Robustness Tests - Using Corruption Dummy}

This table reports the impacts of AFS on an alternative measure of corruption obstacles, Corruption Dummy. The OLS regression results are reported in Columns (1) and (3), while Ordered Probit regression results are reported in Columns (2) and (4). Macro controls, industry and year fixed effects are included in all regressions. Country fixed effects are included in Columns (3) and (4). Standard errors, clustered by country, are reported in parentheses. Detailed variable definitions and sources are given in Appendix 2. ${ }^{* * *},{ }^{* *}$, and ${ }^{*}$ indicate statistical significance at the $1 \%, 5 \%$, and $10 \%$ levels, respectively.

\begin{tabular}{|c|c|c|c|c|}
\hline \multirow[t]{2}{*}{ Dep. Var. } & \multicolumn{4}{|c|}{ Corruption Dummy } \\
\hline & $\begin{array}{l}\text { OLS/LPM } \\
\text { (1) }\end{array}$ & $\begin{array}{l}\text { Probit } \\
(2)\end{array}$ & $\begin{array}{l}\text { OLS/LPM } \\
\text { (3) }\end{array}$ & $\begin{array}{l}\text { Probit } \\
\text { (4) }\end{array}$ \\
\hline AFS & $\begin{array}{l}0.0457^{* * *} \\
(0.0148)\end{array}$ & $\begin{array}{l}0.1198 * * * \\
(0.0402)\end{array}$ & $\begin{array}{l}0.0137 * * \\
(0.0065)\end{array}$ & $\begin{array}{l}0.0417 * * \\
(0.0192)\end{array}$ \\
\hline Ln Firm Size & $\begin{array}{l}-0.0035 \\
(0.0028)\end{array}$ & $\begin{array}{l}-0.0097 \\
(0.0080)\end{array}$ & $\begin{array}{l}0.0005 \\
(0.0023)\end{array}$ & $\begin{array}{l}0.0017 \\
(0.0066)\end{array}$ \\
\hline Ln Firm Age & $\begin{array}{l}0.0117^{* *} \\
(0.0059)\end{array}$ & $\begin{array}{l}0.0318^{* *} \\
(0.0159)\end{array}$ & $\begin{array}{l}0.0059 * * \\
(0.0030)\end{array}$ & $\begin{array}{l}0.0176 * * \\
(0.0088)\end{array}$ \\
\hline Experience & $\begin{array}{l}0.0006 \\
(0.0004)\end{array}$ & $\begin{array}{l}0.0016 \\
(0.0011)\end{array}$ & $\begin{array}{l}-0.0001 \\
(0.0003)\end{array}$ & $\begin{array}{l}-0.0003 \\
(0.0009)\end{array}$ \\
\hline Government & $\begin{array}{l}-0.2088 * * * \\
(0.0442)\end{array}$ & $\begin{array}{l}-0.6524^{* * *} \\
(0.1256)\end{array}$ & $\begin{array}{l}-0.0963 * * \\
(0.0378)\end{array}$ & $\begin{array}{l}-0.3789 * * * \\
(0.1225)\end{array}$ \\
\hline Foreign & $\begin{array}{l}-0.0144 \\
(0.0119)\end{array}$ & $\begin{array}{l}-0.0379 \\
(0.0330)\end{array}$ & $\begin{array}{l}-0.0057 \\
(0.0091)\end{array}$ & $\begin{array}{l}-0.0162 \\
(0.0270)\end{array}$ \\
\hline Exporter & $\begin{array}{l}0.0241^{* * *} \\
(0.0082)\end{array}$ & $\begin{array}{l}0.0676 * * * \\
(0.0227)\end{array}$ & $\begin{array}{l}0.0187^{* * *} \\
(0.0063)\end{array}$ & $\begin{array}{l}0.0546^{* * *} \\
(0.0184)\end{array}$ \\
\hline Compete & $\begin{array}{l}0.0970 * * * \\
(0.0132)\end{array}$ & $\begin{array}{l}0.2659 * * * \\
(0.0339)\end{array}$ & $\begin{array}{l}0.0880 * * * \\
(0.0092)\end{array}$ & $\begin{array}{l}0.2588^{* * *} \\
(0.0261)\end{array}$ \\
\hline Capital Expenditure & 0.0187 & 0.0518 & $0.0210 *$ & $0.0637^{* *}$ \\
\hline
\end{tabular}




$\begin{array}{lllll} & (0.0122) & (0.0333) & (0.0107) & (0.0317) \\ \text { Public } & -0.0104 & -0.0257 & -0.0257^{* *} & -0.0758^{* *} \\ & (0.0191) & (0.0551) & (0.0130) & (0.0372) \\ \text { Company } & 0.0138 & 0.0433 & 0.0039 & 0.0106 \\ & (0.0159) & (0.0464) & (0.0077) & (0.0228) \\ & & & & \text { Yes } \\ \text { Industry Fixed Effects } & \text { Yes } & \text { Yes } & \text { Yes } & \text { Yes } \\ \text { Year Fixed Effects } & \text { Yes } & \text { Yes } & \text { Yes } & \text { Yes } \\ \text { Country Fixed Effects } & \text { No } & \text { No } & & \\ N & & & 102,016 & 102,016 \\ R^{2} / \text { Pseudo R } & 102,016 & 102,016 & 0.18 & 0.15\end{array}$




\section{Table IA2. Regression Discontinuity Design (RDD) Thresholds}

This table presents employee threshold for the audit requirements of financial statements. We collect all employee threshold information from the website of the International Federation of Accountants, the legal and regulatory environment section (https://www.ifac.org/). Threshold determination examples:

Greece: Greece's accounting Law 4449/2017 stipulates that “Under the law, all public interest entities and all companies that meet two of the following criteria for two consecutive years are subject to mandatory statutory audits: (i) total assets of EU 4,000,000; (ii) net turnover of EU 8,000,000; and (iii) average employees of 50 for the year."

The Greece law requires enterprises to be audited when certain criteria are met. One criterion is the average employees of 50 for the year. We hence set the threshold to 50.

Hungary: "Companies surpassing both of the following thresholds must undergo a statutory audit: (i) the annual net sales (calculated for the period of one year) exceed HUF 300 million on the average of the two financial years preceding the financial year under review and (ii) the average number of people employed by the undertaking exceed 50 people on the average of the two financial years preceding the financial year under review."

The law requires enterprises with more than 50 employees to be audited. We hence set the threshold to 51.

\begin{tabular}{llll}
\hline Country & Survey year(s) & Total obs. & Threshold \\
\hline Albania & $2007,2013,2019$ & 1,041 & 251 \\
Benin & 2009,2016 & 300 & 51 \\
Bosnia and Herzegovina & $2009,2013,2019$ & 1,083 & 50 \\
Bulgaria & $2007,2009,2013$ & 1,596 & 51 \\
Burkina Faso & 2009 & 394 & 51 \\
Cambodia & 2013,2016 & 845 & 101 \\
Cameroon & 2009,2016 & 724 & 51 \\
Croatia & $2007,2013,2019$ & 1,397 & 51 \\
Cyprus & 2019 & 240 & 51
\end{tabular}




\begin{tabular}{|c|c|c|c|}
\hline Czech Republic & 2009, 2013 & 504 & 50 \\
\hline Fiji & 2009 & 164 & 51 \\
\hline Georgia & 2008,2013 & 733 & 251 \\
\hline Greece & 2018 & 600 & 50 \\
\hline Hungary & 2009,2013 & 601 & 51 \\
\hline Italy & 2019 & 760 & 20 \\
\hline Ivory Coast & 2009, 2016 & 887 & 51 \\
\hline Kenya & 2007, 2013, 2018 & 2,439 & 251 \\
\hline Kosovo & 2009, 2013 & 472 & 51 \\
\hline Latvia & 2009, 2013 & 607 & 51 \\
\hline Lebanon & 2013 & 561 & 26 \\
\hline Lithuania & 2009, 2013 & 546 & 51 \\
\hline Moldova & 2009, 2013, 2019 & 1,083 & 51 \\
\hline Mongolia & 2009, 2013, 2019 & 1,082 & 200 \\
\hline Montenegro & 2009, 2013, 2019 & 416 & 51 \\
\hline Mozambique & 2007,2018 & 1,080 & 501 \\
\hline North Macedonia & 2009, 2013 & 726 & 51 \\
\hline Papua New Guinea & 2015 & 65 & 101 \\
\hline Poland & 2009, 2013 & 997 & 50 \\
\hline Romania & 2009,2013 & 1,081 & 51 \\
\hline Rwanda & 2006,2011 & 453 & 51 \\
\hline Senegal & 2007,2014 & 1,107 & 51 \\
\hline Serbia & $2009,2013,2019$ & 1,109 & 51 \\
\hline Sierra Leone & 2009, 2017 & 302 & 51 \\
\hline Slovak Republic & 2009, 2013 & 543 & 31 \\
\hline Slovenia & 2009, 2013 & 546 & 50 \\
\hline Sri Lanka & 2011 & 610 & 1000 \\
\hline Suriname & 2010, 2018 & 385 & 51 \\
\hline
\end{tabular}




\begin{tabular}{llll} 
Togo & 2009,2016 & 305 & 51 \\
Tunisia & 2013 & 592 & 10 \\
Turkey & $2008,2013,2019$ & 4,159 & 201 \\
Ukraine & 2008,2013 & 1,853 & 51 \\
\hline Total & & 34,988 & \\
\hline
\end{tabular}

